Article

\title{
Assessment of an Integrated and Sustainable Multistage System for the Treatment of Poultry Slaughterhouse Wastewater
}

\author{
Phumeza Akhona Dyosile ${ }^{1}$, Cebisa Mdladla ${ }^{1}$, Mahomet Njoya ${ }^{1}\left(\mathbb{C}\right.$, Moses Basitere ${ }^{2, *}$, \\ Seteno Karabo Obed Ntwampe ${ }^{3(1)}$ and Ephraim Kaskote ${ }^{4}$
}

1 Bioresource Engineering Research Group (BioERG), Cape Peninsula University of Technology, Symphony Way, Bellville Campus, Cape Town 7535, South Africa; phumezadyosile@gmail.com (P.A.D.); mdladlacebisa44@gmail.com (C.M.); mahomet.njoya@gmail.com (M.N.)

2 Academic Support Programme for Engineering in Cape Town (ASPECT) \& Water Research Group, Department of Civil Engineering, University of Cape Town, Rondebosch, Cape Town 7700, South Africa

3 Centre of Excellence in Carbon-Based Fuels, School of Chemical and Minerals Engineering, North West University, Private Bag X1290, Potchefstroom 2520, South Africa; Karabo.Ntwampe@nwu.ac.za

4 Malutsa (Pty) Ltd., c/o Oude Pont and Meent Street (Malutsa House), Wellington Industrial Park, Wellington 7655, South Africa; ephraimk@malutsa.co.za

* Correspondence: moses.basitere@uct.ac.za; Tel.: +27-738706901

\section{check for} updates

Citation: Dyosile, P.A.; Mdladla, C.; Njoya, M.; Basitere, M.; Ntwampe, S.K.O.; Kaskote, E. Assessment of an Integrated and Sustainable

Multistage System for the Treatment of Poultry Slaughterhouse

Wastewater. Membranes 2021, 11, 582. https://doi.org/10.3390/

membranes11080582

Academic Editors: Geoffroy Lesage and Amine Charfi

Received: 24 June 2021

Accepted: 26 July 2021

Published: 30 July 2021

Publisher's Note: MDPI stays neutral with regard to jurisdictional claims in published maps and institutional affiliations.

Copyright: (c) 2021 by the authors Licensee MDPI, Basel, Switzerland. This article is an open access article distributed under the terms and conditions of the Creative Commons Attribution (CC BY) license (https:/ / creativecommons.org/licenses/by/ $4.0 /)$.

\begin{abstract}
This paper assesses the performance of an integrated multistage laboratory-scale plant, for the treatment of poultry slaughterhouse wastewater (PSW). The system was comprised of an eco-flush dosed bio-physico pre-treatment unit for fats, oil, and grease (FOG) hydrolysis prior to the PSW being fed to a down-flow expanded granular bed reactor (DEGBR), coupled to a membrane bioreactor (DEGBR-MBR). The system's configuration strategy was developed to achieve optimal PSW treatment by introducing the enzymatic pre-treatment unit for the lipid-rich influent (PSW) in order to treat FOG including odour causing constituents such as $\mathrm{H}_{2} \mathrm{~S}$ known to sour anaerobic digestion (AD) such that the PSW pollutant load is alleviated prior to AD treatment. This was conducted to aid the reduction in clogging and sludge washout in the DEGBR-MBR systems and to achieve the optimum reactor and membrane system performance. A performance for the treatment of PSW after lipid reduction was conducted through a qualitative analysis by assessing the pre- and post-pre-treatment units' chemical oxygen demand (COD), total suspended solids (TSS), and FOG concentrations across all other units and, in particular, the membrane units. Furthermore, a similar set-up and operating conditions in a comparative study was also performed. The pre-treatment unit's biodelipidation abilities were characterised by a mean FOG removal of $80 \%$ and the TSS and COD removal reached 38 and 56\%, respectively. The final acquired removal results on the DEGBR, at an OLR of $~ 18-45 \mathrm{~g}$ COD/L.d, was 87, 93, and 90\% for COD, TSS, and FOG, respectively. The total removal efficiency across the pre-treatment-DEGBR-MBR units was $99 \%$ for COD, TSS, and FOG. Even at a high OLR, the pre-treatment-DEGBR-MBR train seemed a robust treatment strategy and achieved the effluent quality set requirements for effluent discharge in most countries.
\end{abstract}

Keywords: down-flow expanded granular bed reactor (DEGBR); expanded granular sludge bed (EGSB); membrane bioreactor (MBR); poultry slaughterhouse wastewater (PSW)

\section{Introduction}

Millions of litres of poultry slaughterhouse wastewater (PSW) are generated annually from a series of process steps used for bird processing for meat, which includes the slaughtering process, meat handling, and cleaning of facilities and equipment [1]. From this, the contaminated wastewater contains a high concentration of organic matter from blood, skin, fats, including nutrients and the chemical pollutants from detergents used to clean holding facilities, bird urine, and faecal matter, thus, making the disposal of this high-strength wastewater perilous [1,2]. Beyond the risks linked to the deterioration of the 
environment, pollution is one of the most pressing environmental health priorities requiring intervention. Similarly, the strength of PSW has been proven to be much higher than domestic wastewater and reduces water-dissolved oxygen, thus, affecting water-dependent species when released into receiving sources untreated [3,4]. While poultry slaughterhouses have employed wastewater treatment units, most are outdated and incapable of achieving suitable contaminant and nutrient reduction as per the set regulations. Overtime, the discharged wastewater may result in sewer line damage, the contamination of water bodies, the pollution of land, and the possible emission of harmful gases from the nutrients and contaminants contained therein [5].

Furthermore, the urgency for effective treatment methods for PSW lie not only in the need for continued wastewater treatment research but can have financial benefits due to the escalating growth demand for poultry products that is aided by the South African agro-economy expansion. However, for such growth to be sustainable, the devastating effect the wastewater has on the environment, growing water use, and demand, water conservation and recycling should be implemented worldwide. Hence, in the efforts to conserve water reserves in an already stressed water scarce country, i.e., South Africa (SA), researchers have since employed various technologies in the pursuit of effective PSW treatment options.

All around the world, biological treatment systems have been explored for PSW treatment due to their efficiency, i.e., nutrient and organic matter removal abilities, using several technologies. Furthermore, these systems are appreciated for their simplicity and reduced hydraulic retention times (HRTs) while handling high organic loading rates (OLRs) [6]. These biological systems contain anaerobic, aerobic, or facultative microorganisms that degrade organics in the PSW [7,8]. However, others [9] substantiated the superiority of anaerobic digestion in comparison to aerobic digestion as a secondary treatment unit, whereby an aerobic system was compared to an anaerobic system in a comparative study using a series of case studies that looked at the up-flow anaerobic sludge blanket (UASB), an activated sludge process, among others. In addition, the study concluded that aerobic systems are recommended for post-treatment, particularly in bigger plants for nutrient removal and further PSW purification to meet the general limit for effluent discharge than as primary systems for PSW [9,10]. Furthermore, some [10] continued and attested aerobic technologies as better post-treatment technologies to best treat the solubilised organics in FOG laden effluent, utilising a system comprised of an anaerobic baffled reactor (ABR) seeded with activated sludge (AS). The study's observations attested to additional organic reduction from 128 and $132 \mathrm{mg} / \mathrm{L}$ to 0.1 and $0.4 \mathrm{mg} / \mathrm{L}$ for total organic carbon (TOC) and COD, respectively. In another research study by [11], an anaerobic-aerobic system using an EGSB coupled with a membrane bioreactor (MBR) was evaluated. The bioreactor achieved a COD average removal of $63 \%$ and, when combined with a MBR, an average of $96 \%$ removal was achieved, thus signifying that the anaerobic-aerobic set-up can be effectively used for PSW treatment. This was substantiated by [10], using a concept of preand-post-treatment.

The anaerobic process has limitations such as high temperature sensitivity, inability to efficiently remove nutrients, and depending on the configuration and operating conditions, clogging of the granular bed due to solids and FOG settling over the bed. Additionally, low to moderate effluent quality and longer start up periods from the acclimation period for the organic matter decomposing microorganisms, were identified as the main drawbacks [12]. Table 1 lists a summary of technologies used and the achieved COD, TSS, and FOG removal efficiency using the anaerobic reactors for the lipid-rich PSW treatments to date. 
Table 1. Achieved effluent quality from past studies for PSW treatment.

\begin{tabular}{|c|c|c|c|c|}
\hline Reactor Technology & Year of Development & $\begin{array}{c}\text { Reactor Development } \\
\text { Rationale and Challenges }\end{array}$ & Performance Results & Reference \\
\hline $\begin{array}{c}\text { Expanded Granular } \\
\text { Sludge Bed } \\
\text { (EGSB) }\end{array}$ & - & $\begin{array}{l}\text { Side recycle stream improves } \\
\text { efficiency due to the increase } \\
\text { in sludge expansion. } \\
\text { Up-flow configuration } \\
\text { resulted in sludge washout } \\
\text { during high FOG and TSS } \\
\text { loading, thus resulting in } \\
\text { methanogen loss, which } \\
\text { reduced biological } \\
\text { degradation. }\end{array}$ & $65 \%$ tCOD removal & [1] \\
\hline $\begin{array}{l}\text { Static Granular Bed } \\
\text { Reactor } \\
\text { (SGBR) }\end{array}$ & 2000 & $\begin{array}{l}\text { An SGBR with a down flow } \\
\text { configuration was developed. } \\
\text { Challenges include clogging } \\
\text { of the underdrain. Hence, } \\
\text { requiring periodic alleviation } \\
\text { through backwash, } \\
\text { disturbing the underdrain } \\
\text { and granular bed build-up. }\end{array}$ & $\begin{array}{c}95 \% \text { COD removal, } 95 \% \\
\text { TSS removal, } 90 \% \text { FOG } \\
\text { removal }\end{array}$ & {$[13,14]$} \\
\hline $\begin{array}{c}\text { Down-flow Expanded } \\
\text { Granular Bed Reactor } \\
\text { (DEGBR) }\end{array}$ & 2019 & $\begin{array}{l}\text { A hybrid of EGSB and SGBR, } \\
\text { with down/top feeding } \\
\text { configuration and a recycle. }\end{array}$ & $\begin{array}{l}99,6 \% \text { COD removal, } \\
93,7 \% \text { FOG removal }\end{array}$ & [8] \\
\hline
\end{tabular}

Despite the positive advances taken, several researchers found that high protein wastewater (such as PSW) results in the production of free ammonia during anaerobic digestion [13]. They recommended a pre-treatment stage to treat the wastewater characteristics for enhanced anaerobic digestion (AD) performance without producing detrimental by-products such as ammonia. Additionally, the authors of [10] indicated that anaerobic processes require pre- and post-treatment steps for the appropriate removal of solids, nutrients, and FOG that tend to clog the AD reactor and piping system thereof, resulting in a reduced reactor performance and an accelerated reactor failure. Furthermore, in up-flow reactors, periodic sludge washout due to suspended solids and high lipid content has been observed [1,12].

To date there have been several pre-treatment methods developed from the findings conducted for AD. Table 2 lists a summary of the effective pre-treatment methods coupled with $\mathrm{AD}$ in numerous studies. From the results, it is also evident that a pre-treatment unit can remove some of the contaminants.

Table 2. Developed pre-treatment technologies and their COD, FOG, and TSS removal efficiency.

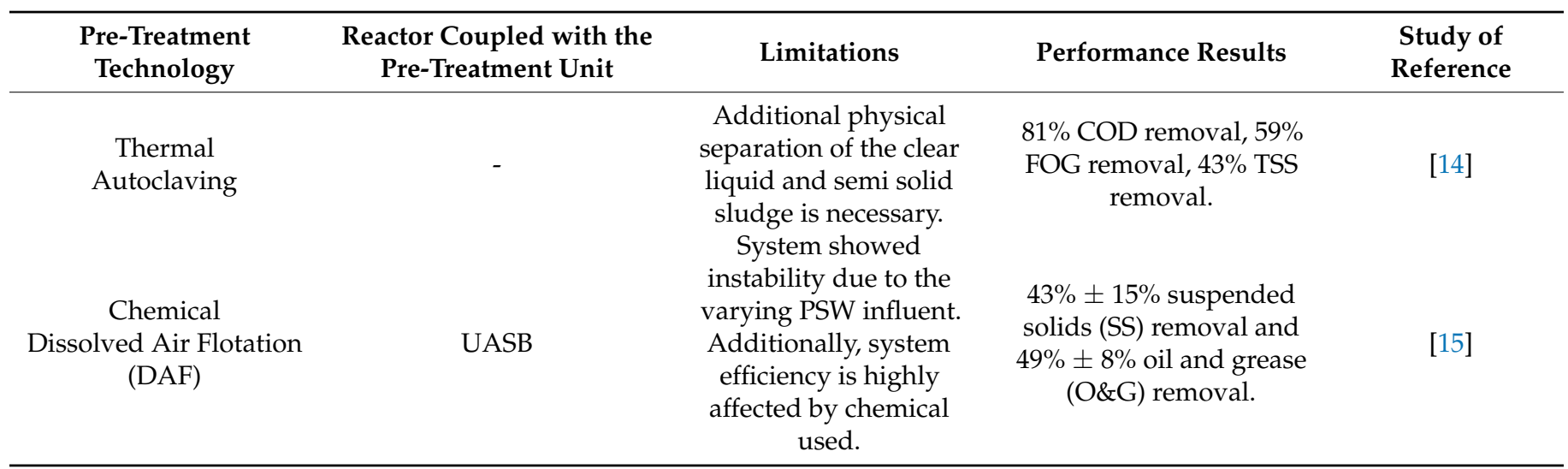


Table 2. Cont

\begin{tabular}{|c|c|c|c|c|}
\hline $\begin{array}{l}\text { Pre-Treatment } \\
\text { Technology }\end{array}$ & $\begin{array}{l}\text { Reactor Coupled with the } \\
\text { Pre-Treatment Unit }\end{array}$ & Limitations & Performance Results & $\begin{array}{l}\text { Study of } \\
\text { Reference }\end{array}$ \\
\hline $\begin{array}{c}\text { Biological } \\
\text { Enzymatic } \\
\text { Pre-treatment }\end{array}$ & - & $\begin{array}{l}\text { Optimal enzyme dose } \\
\text { is not yet established. } \\
\text { Though the increase in } \\
\text { dose results in } \\
\text { increased free fatty acid } \\
\text { and VSS treatment, the } \\
\text { dose has an optimal } \\
\text { point where higher } \\
\text { doses do not contribute } \\
\text { to increased } \\
\text { effectiveness. }\end{array}$ & $\begin{array}{l}\text { Increase in free fatty acids } \\
\text { and } 10 \% \text { hydrolysis } \\
\text { promotion due to lipase, } \\
88 \% \text { COD reduction in } \\
\text { PSW. }\end{array}$ & {$[13,16,17]$} \\
\hline $\begin{array}{l}\text { Hydrodynamic } \\
\text { Cavitation }\end{array}$ & - & $\begin{array}{l}\text { Optimum conditions } \\
\text { included addition of } \\
\text { Fenton reagent. }\end{array}$ & $\begin{array}{l}\text { Increased COD treatment } \\
\text { to } 44.2 \% \text {. Biological } \\
\text { oxidation treatment time } \\
\text { reduction from } 60 \text { to } 36 \mathrm{~h} \text {. }\end{array}$ & [18] \\
\hline
\end{tabular}

Similarly, there are post-treatment technologies that can be used, among which membrane bioreactors are the most researched. These reactors sometimes consist of activated sludge and membranes that contain distinct pores that remove dissolved organic and inorganic contaminants by providing a physical barrier that filters out pollutants and bacteria [19]. Many studies have included membrane bioreactors as a tertiary treatment stage achieving exceptional results as high as $98->99 \%$ removal efficiency $[19,20]$.

Similarly, post AD, a membrane unit was installed for the further purification of the formed by-products during the AD process [8], subsequently assisting in the further remediation of the wastewater. Submerged membranes are well known for fouling primarily in high FOG wastewater such as that from poultry slaughterhouses. As per the Membrane Bioreactor Task Force of the Water Environment Federation (WEF) (2012), MBR requires coarse influent screening, grit removal, fine screening, and primary clarification, all of which are pre-treatment technologies. Therefore, studying the effectiveness of a combined pre-treatment, an $\mathrm{AD}$ bioreactor, and a submerged membrane system is, therefore, crucial for this study. As shown in Figures 1 and 2, a set-up as illustrated was used in this study for the treatment of PSW.

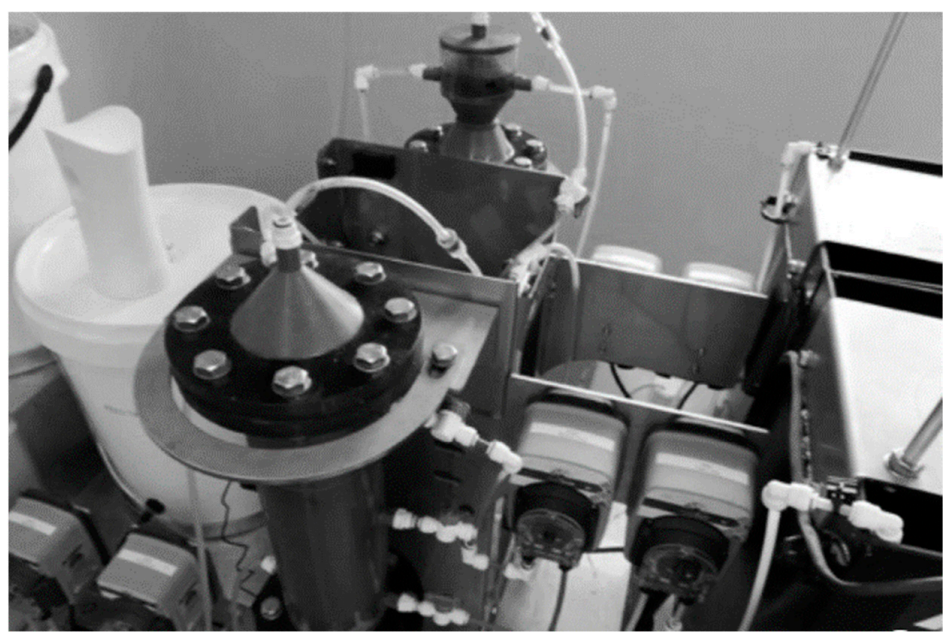

Figure 1. Lab-Scale Treatment Plant for PSW [21]—Reprinted from Membranes, vol 11, Meyo, H.B.; Njoya, M.; Basitere, M.; Ntwampe, S.K.O.; Kaskote, E., “Treatment of Poultry Slaughterhouse Wastewater (PSW) Using a Pre-treatment Stage, an Expanded Granular Sludge Bed Reactor (EGSB), and a Membrane Bioreactor (MBR)". Copyright (2021), with permission from MDPI. 
From previous studies, the recommendations included a thorough pre-treatment step to rid the PSW of solidified FOG in order to enhance the AD reactor's performance $[1,22]$. From the identified gaps, this research included a performance review on a biological pre-treatment stage using a commercial product, i.e., Eco-flush ${ }^{\mathrm{TM}}$ as an additive providing active enzymes for FOG hydrolysis. With the pre-treatment process in place, this study further investigated the performance of the treatment of PSW after the FOG reduction in the pre-treatment unit. Furthermore, the efficacy of the MBRs as a post treatment technology was also investigated.

Lastly, the performance of the full pre-treatment, $\mathrm{AD}$, and MBR chain was investigated.

\section{Materials and Methods}

\subsection{PSW Sampling}

PSW was collected from a local abattoir in the Western Cape, SA. The sample was drawn from an in-between slaughtering process and wastewater processing stage to acquire a representative raw PSW sample. For preservation, the wastewater was stored in a temperature-controlled unit at $5{ }^{\circ} \mathrm{C}$. A representative sample was taken to study the COD, TSS, and FOG of the raw incoming PSW in comparison to the established raw PSW average conditions, as shown in Table 3.

Table 3. PSW Characteristics.

\begin{tabular}{clccccc}
\hline Parameter & Units & Minimum & Maximum & Average & Reference & This Study \\
\hline COD & $\mathrm{mg} / \mathrm{L}$ & 4100 & 9100 & 4317 & {$[23]$} & $6500-21,000$ \\
TSS & $\mathrm{mg} / \mathrm{L}$ & 1580 & 3750 & $2800 \pm 950$ & {$[23,24]$} & $2985-8363$ \\
FOG & $\mathrm{mg} / \mathrm{L}$ & 280 & 8228 & $1655 \pm 1880$ & {$[8]$} & $640-4500$ \\
\hline
\end{tabular}

\subsection{Experimental Set-Up}

The set-up configuration is as shown in Figure 2. All the units had biogas collection ports, although this did not form part of this study.

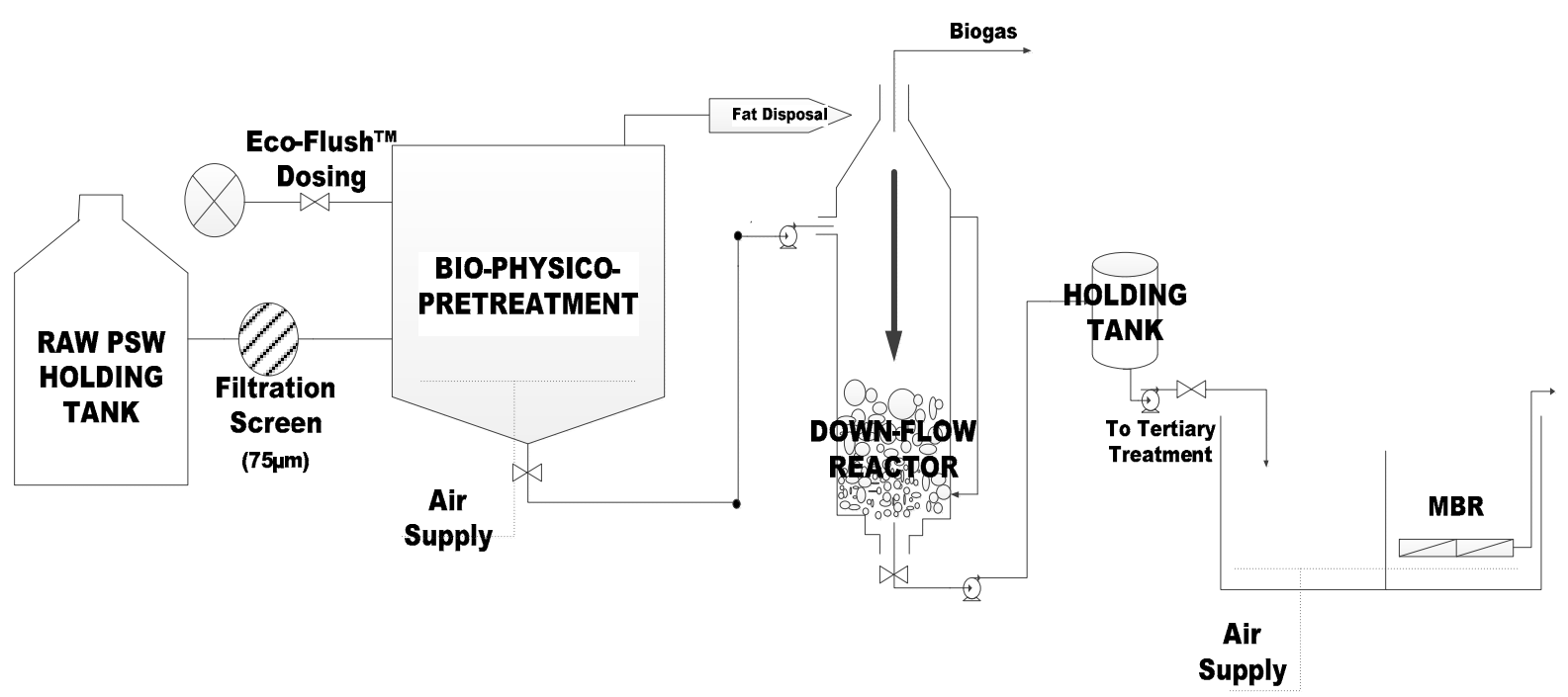

Figure 2. Process Flow Diagram of the Treatment Plant.

\subsubsection{Pre-Treatment Unit Set-Up}

The PSW was pre-treated by dosing $20 \mathrm{~mL}$ of Eco-Flush ${ }^{\mathrm{TM}}$, supplied by Mavu Biotechnologies (Pty) Ltd., (Cape Town, South Africa) into a 20-litre pre-treatment tank with raw PSW. The Eco-flush ${ }^{\mathrm{TM}}$ contained a complex mixture of microorganisms, including aerobic, anaerobic, nitrifying, and sulphur oxidising bacteria combined with fungi and enzymes 
associated with the hydrolysis of FOG, i.e., the dissociation of bonds between the triglycerides and phospholipase resulting in a glycerol and fatty acid separation. Furthermore, not only does Eco-flush ${ }^{\mathrm{TM}}$ aid the reduction in FOG content in PSW, it also contains a bacterial mixture that synergistically produces enzymes (in a nutrient rich environment) that accelerate the decomposition of organic matter and oxidation of ammonia into nitrates and nitrites [25].

A Resun air pump (Ac 9906) from Hydroponic in Cape Town, South Africa, was used to sparge air into the pre-treatment tank using silicone tubing. The silicone tubing used to pump air into the pre-treatment tank was connected to two diffusers to provide sufficient micro-bubble formation into the system. This ensured that there was an adequate dissolved air supply to create the optimum conditions for aerobic bacteria to be most effective. The mixture was aerated for $24 \mathrm{~h}$ then allowed to settle for a further $24 \mathrm{~h}$ to allow the Eco-Flush ${ }^{\mathrm{TM}}$ time to adequately digest the FOG and decouple proteins within the PSW and to reduce the level of $\mathrm{H}_{2} \mathrm{~S}$, which is known to deactivate anaerobic bacteria. The pre-treated PSW was then filtered with a 75-micrometre Madison Test sieve into a pre-treatment tank, which feeds into both the EGSB (previous study and for comparison) and DEGBR. The PSW to the AD systems was continuously stirred with a stirrer to keep the feed in a homogeneous state. The treatment process is depicted in Figure 3.

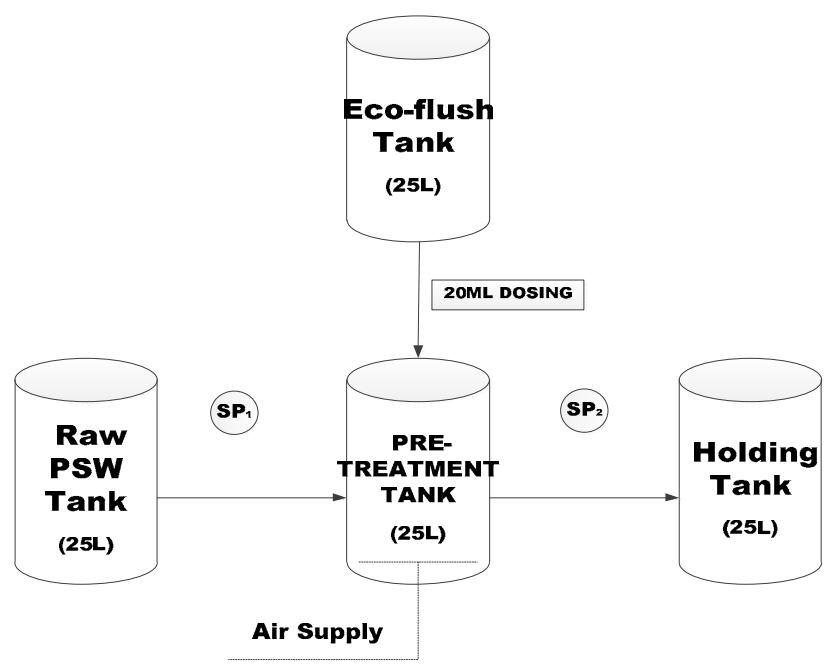

Figure 3. Pre-treatment Experimental Set-up ( $\mathrm{SP}=$ sample point).

\subsubsection{Bioreactor Experimental Set-Up}

Laboratory scale (2 L) Polyvinylchloride $( \pm 600 \times 110 \mathrm{~cm})$ DEGBR and EGBS reactors, were simultaneously set up parallel to each other, as illustrated in Figure 4. Each reactor was connected to a feed holding tank containing pre-treated filtered feed from the Eco-flush ${ }^{\mathrm{TM}}$ pre-treatment unit (Illustrated in Figure 4).

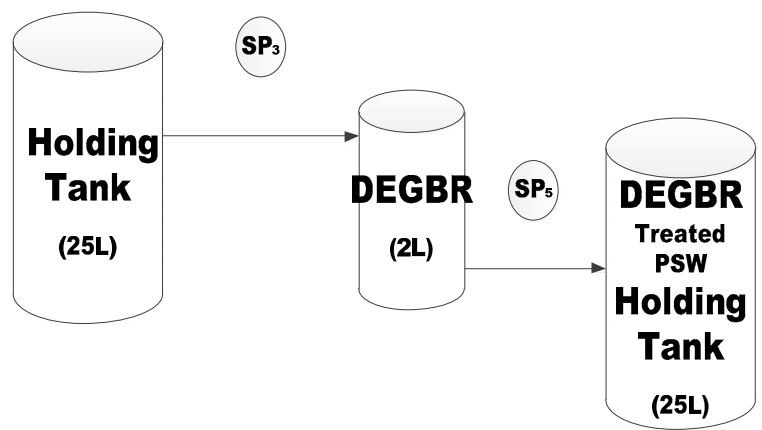

Figure 4. Reactor (EGSB and DEGBR) Set-up. (SP = sample point). 
The reactors were inoculated with anaerobic granules from an USAB operated at a local brewing house situated in Newlands, Cape Town. A volume (200 mL) of 50\% v/w dry milk was used as a source of carbon and was fed to the granules, to assist with the acclimation of the anaerobic biomass.

For optimal acclimation, mesophilic temperatures $\left(29-36{ }^{\circ} \mathrm{C}\right)$ were maintained by connecting an external water bath to the reactors jacket. Reactor inoculation took a period of $72 \mathrm{~h}$ prior to running the reactors at $0.36 \mathrm{~L} / \mathrm{h}$ and had an HRT of 5.71hr. Product released was stored in separate holding tanks for individual performance analysis conducted at an SANAS-accredited external laboratory, i.e., City of Cape Town Scientific Services.

\subsubsection{Membrane Bioreactor Units Set-Up}

- Membrane Bioreactor design

Hydrophilic polyethersulfone (PES) membranes with a 0.04-mirometre pore size and a glycerine $(20 \%)$ / sodium benzoate $(3 \%)$ preservative were housed in a $315 \times 182 \times 69$ mm polyvinyl chloride (PVC) module with a polyester (PET) drainage layer. The casts were submerged in $100 \mathrm{~L}$ aerated tanks, as illustrated in Figure 5.

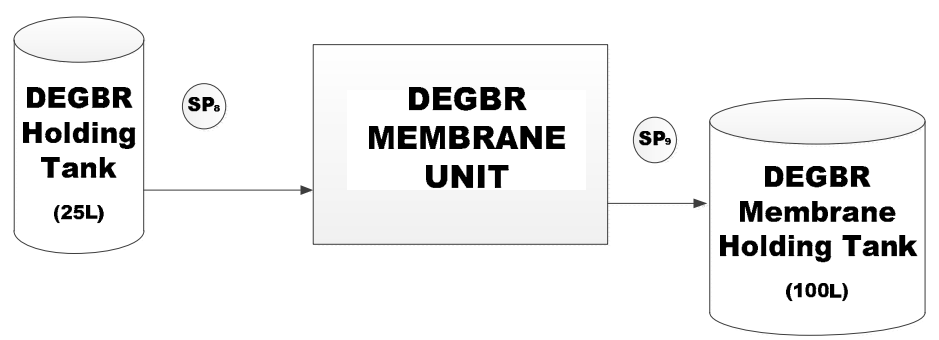

Figure 5. Membrane Bioreactor Unit Set-up. (SP=sample point).

- Inoculation and Operating Conditions

The EGSB-MBR and DEGBR-MBR had identical set-up conditions. A volume (25 L) of AD-treated PSW was filled in each tank. The aerated MBR systems acclimatised for a period of $48 \mathrm{~h}$ prior to the filtration cycle start-up at low flow rates of $0.36 \mathrm{~L} / \mathrm{h}$. The observed operated conditions included a temperature range of $5-40{ }^{\circ} \mathrm{C}$ and $\mathrm{pH}$ range of $2-11$.

\subsection{Sampling Points and Analysis}

The sample point is as demonstrated in Figure 3 as $\mathrm{SP}_{2}$. Samples of the pre-treated PSW were taken every second day, while sampling points for the DEGBR were collected from $\mathrm{SP}_{3}$ and $\mathrm{SP}_{5}$, respectively, as illustrated in Figure 4. After the MBR was inoculated, the samples for the DEGBR-MBR systems were collected weekly at $\mathrm{SP}_{9}$, as shown in membrane set-up unit (Figure 5).

Once collected, the samples were stored at cooling storage at $5^{\circ} \mathrm{C}$ to avoid acidification prior to analysis. See Table 4 for methods.

Table 4. Sample Analysis Methods.

\begin{tabular}{ll}
\hline Parameter & Method \\
\hline Temperature & EPA method 9040C \\
Total suspended solids (TSS) & EPA method 160.2 \\
Total chemical oxygen demand (tCOD) & EPA method 410.4 \\
Fats, oils, and grease (FOG) & EPA method 10056 \\
\hline
\end{tabular}




\section{Results and Discussion \\ 3.1. Pre-Treatment Performance Evaluation}

The development of the treatment plant used for this study included the Eco-flush ${ }^{\mathrm{TM}}$ dosed bio-physico aerated pre-treatment unit that encouraged FOG coagulation and hydrolysis, which reduced the risk of FOG accumulation in the reactor bed and piping system [25]. After the 24-h aeration period, the enzyme activity had facilitated the effective separation of glycerol from the lipid-rich PSW through hydrolysis, thus, corroborating research from other studies [13], whereby it was concluded that hydrolysis promotion was evident in the Eco-flush ${ }^{\mathrm{TM}}$ dosed pre-treatment unit, hypothesised to be facilitated through lipase action. Figure 6 depicts the pre-treatment operation and FOG collected after coagulation.

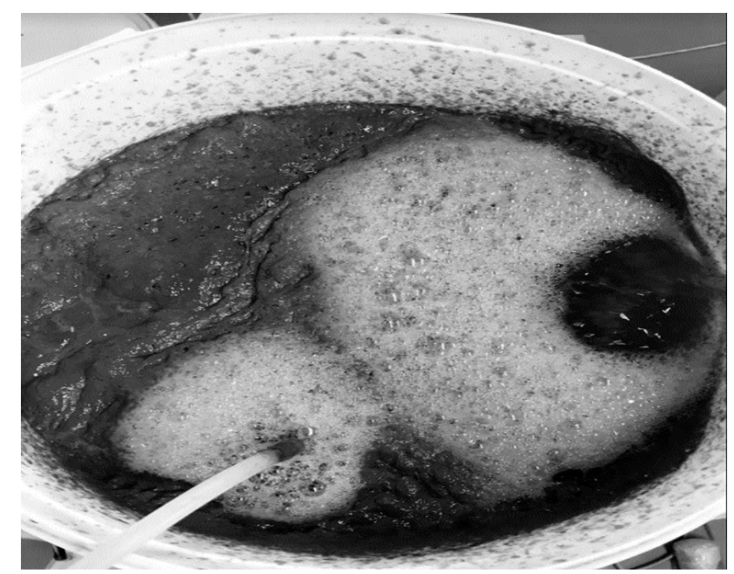

(a)

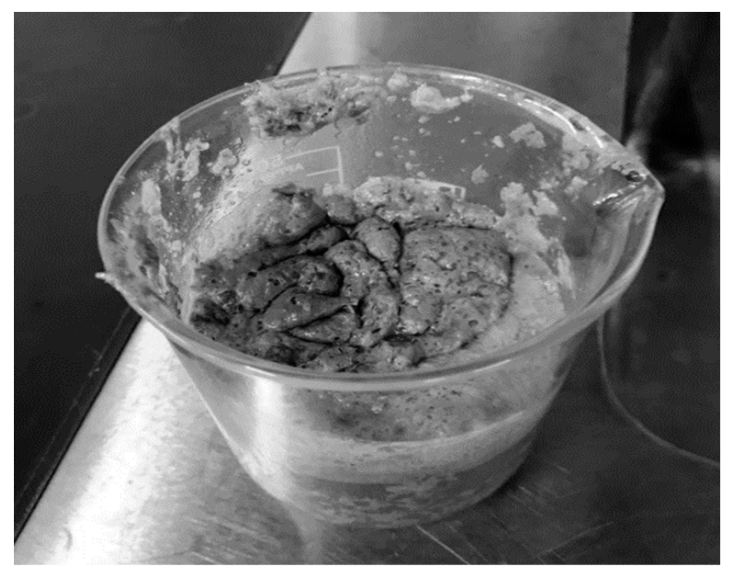

(b)

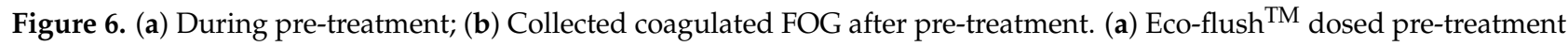
during and after $24 \mathrm{~h}$ aeration when the enzymatic pre-treatment is employed, (b) The coagulated FOG collected from the top of the pre-treatment unit.

The performance of the pre-treatment stage used in this study is illustrated in Figure 7, which depicts the variation of key water quality assessment parameters as well as their removal efficiencies throughout the study. These parameters were not pre-processed to exclude outliers that may have been identified during the experiment. To identify these outliers, boxplots (see Figure 8a) were used. According to Figure 8a, outliers were identified in the distribution of the inlet FOG and COD, as well as the outlet COD. These outliers can be less clearly observed in Figure 7, which depicts the variation of these parameters throughout the study. To identify these outliers, the interquartile range rule was used, and they were, subsequently, replaced by the median value of respective distribution to correct the effects of the outliers.

The boxplot redacted performance profile of the PSW pre-treatment stage is displayed in Figure 9, from which it can be observed that this treatment stage performed well for the removal of FOG ( 65 to $\sim 92 \%$ ) and TSS ( $\sim 45$ to $\sim 72 \%$ ), with an insignificant removal of COD ( 25 to $\sim 52 \%)$ in comparison to the literature $[13,16,17]$. An evaluation of a possible correlation between these removal efficiencies was conducted in Figure 10, which depicts a correlation matrix with Pearson's correlation coefficient (r) and the $p$-value for hypothesis testing. Usually, an R-value above 0.75 translates to a considerable correlation between the assessed parameters, which can be confirmed with a $p$-value $\leq 0.05$. However, the removal values displayed in Figure 10 showed no correlation between the COD, FOG, and TSS removal efficiencies for the pre-treatment unit. 

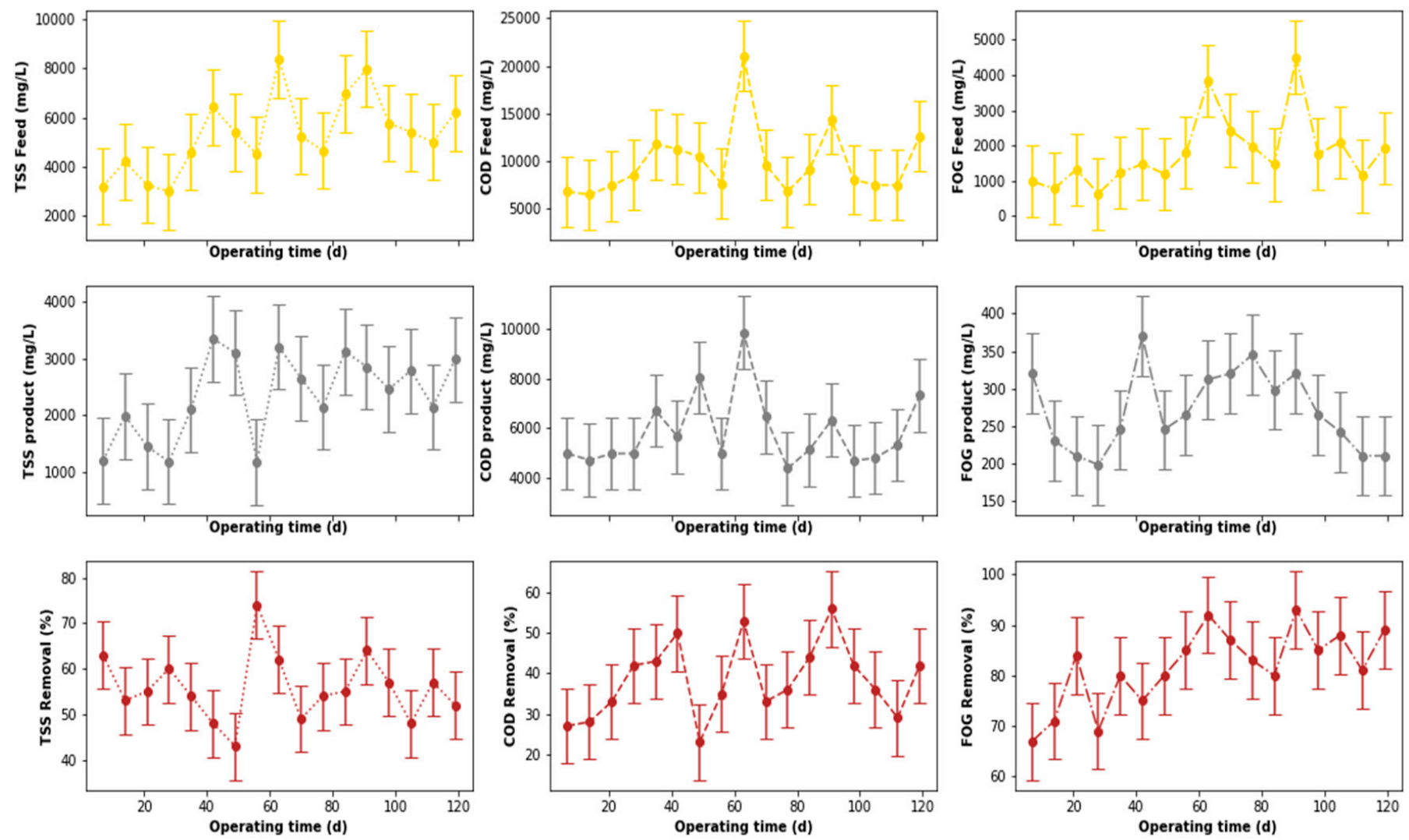

Figure 7. Performance of PSW pre-treatment stage before outliers' detection and replacement.

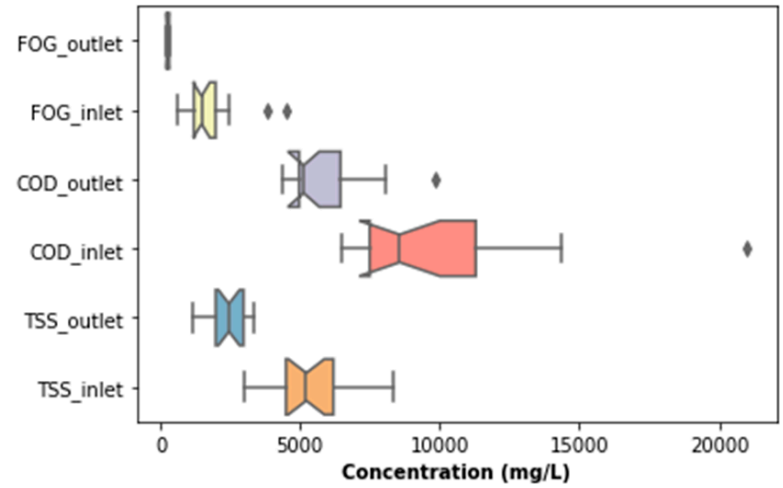

(a)

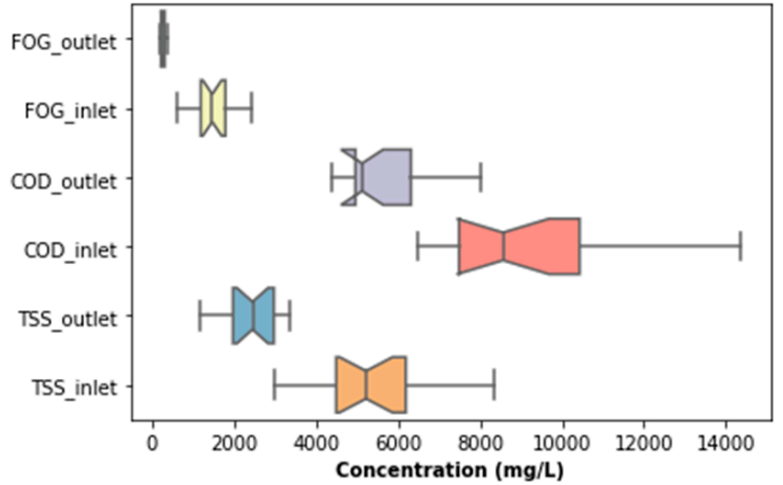

(b)

Figure 8. Boxplots of highlighted features before and after outliers' replacement: (a) Boxplots before outliers' replacement; (b) Boxplots after outliers' replacement. 

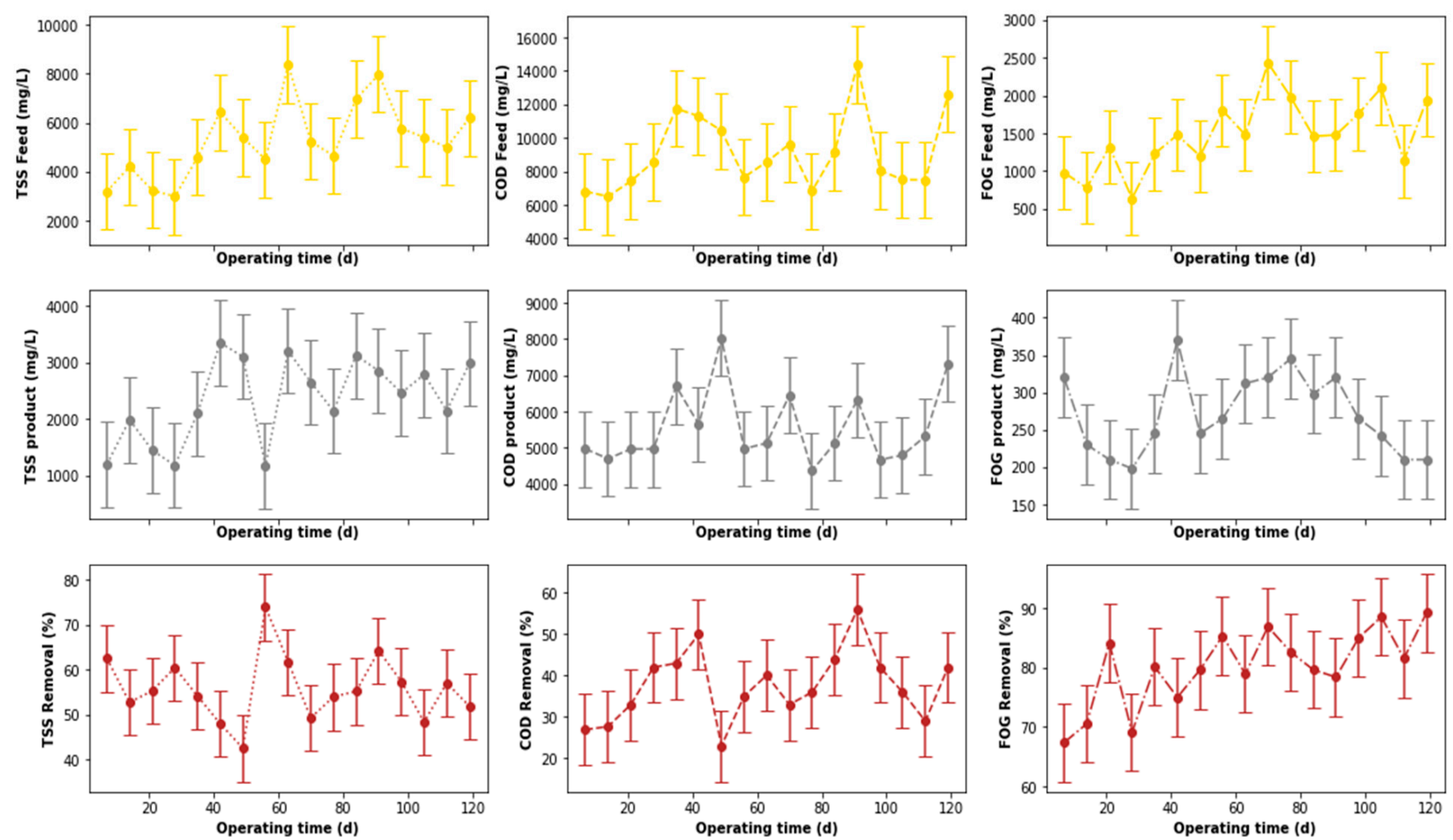

Figure 9. Performance of PSW pre-treatment stage after outliers' detection and replacement.
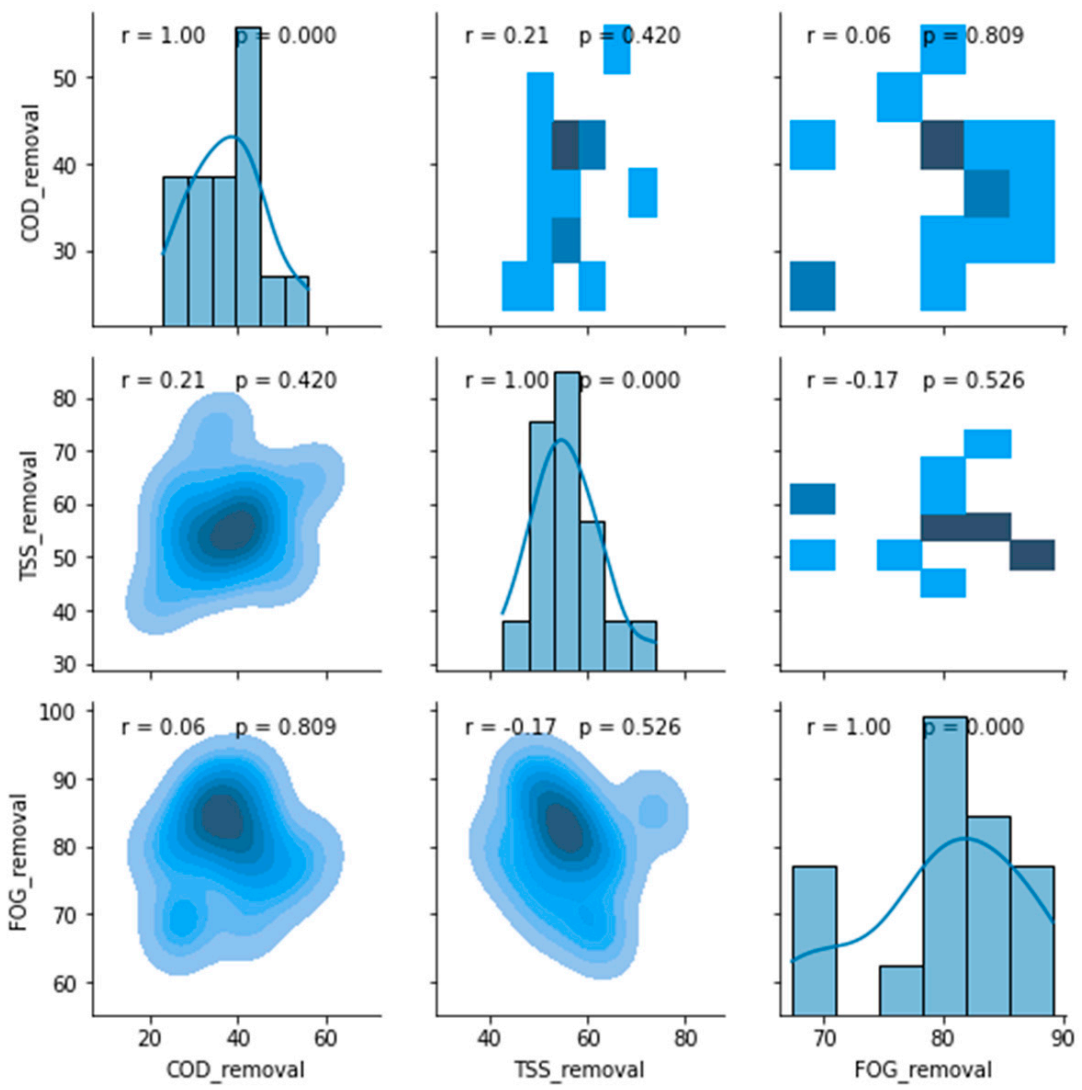

Figure 10. Correlation matrix between removal efficiencies of the pre-treatment stage. 
A further evaluation of the distribution of the removal efficiencies is depicted in Figure 11, which provides the density distribution, the skewness, the kurtosis, and the mean of the COD, TSS, and FOG distributions. Overall, as initially intended, the pretreatment stage performed the best for FOG removal as designed, with a mean FOG percentage removal of $80 \%$ (see Figure 11), while the mean percentage removal of the COD and TSS, were 38 and $56 \%$, respectively. The skewness of each of these distributions was low, but varied with different kurtosis values, as depicted in Figure 11.
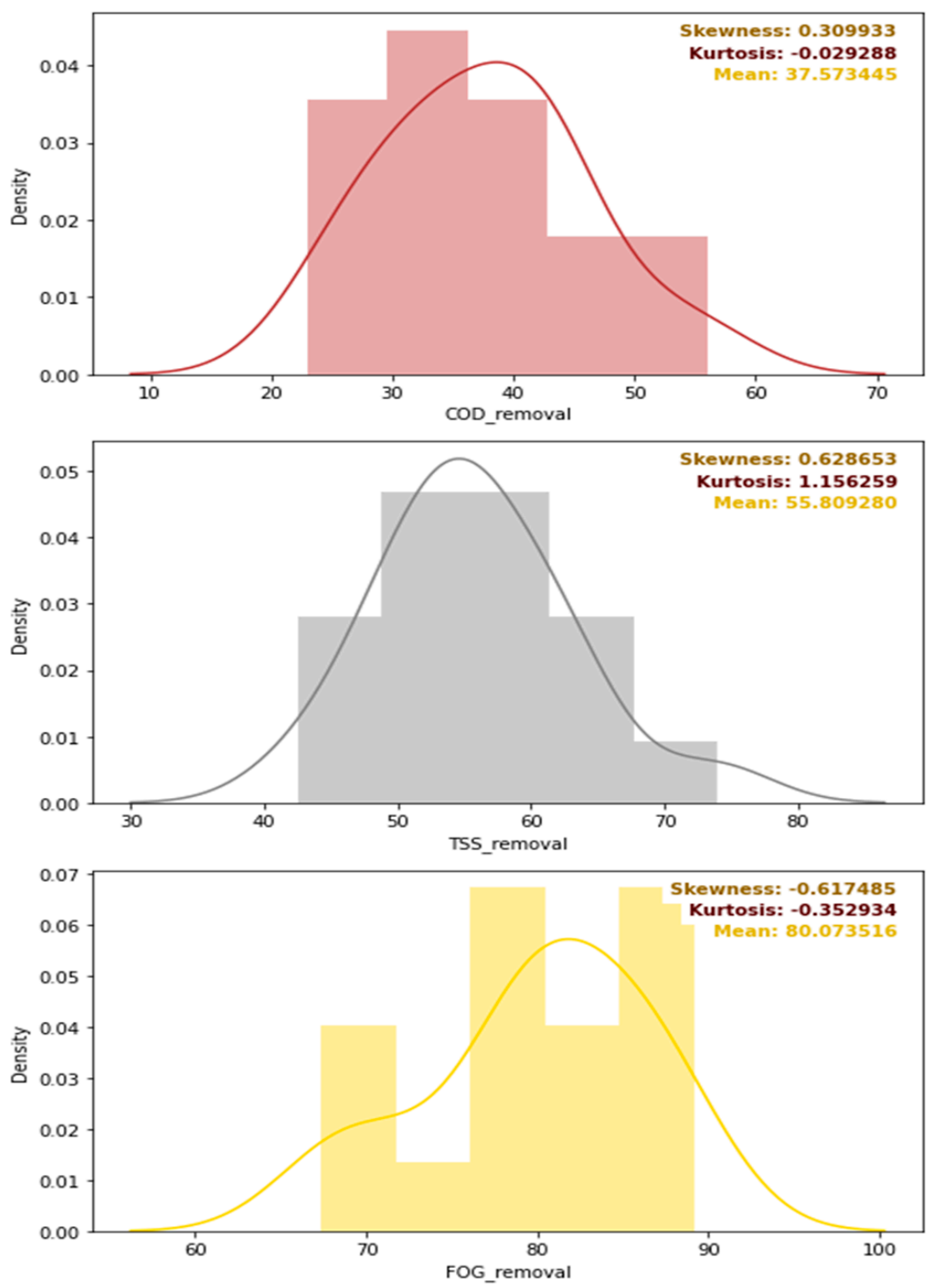

Figure 11. Density distribution, skewness, kurtosis, and mean values of the removal efficiencies of the pre-treatment stage.

\subsection{DEGBR Treatment Performance}

The output from the pre-treatment stage was separated into two streams. The first was supplied to the DEGBR, and the second to the EGSB. The output from both bioreactors was further treated separately using MBR systems receiving AD-treated effluent from both system types. Therefore, this section of the study evaluated the performance of the DEGBR as a secondary stage for the treatment of PSW. The variation of the assessment parameters used to conduct this evaluation is depicted in Figure 12, whereby the removal efficiencies above 65 to $~ 95 \%$ were noticed for each water quality parameter evaluated (COD, FOG, 
and TSS), which exceeded the FOG removal attained by previous studies [8]. To further consolidate these observations, the presence of outliers was also evaluated using boxplots, as depicted in Figure 13a, whereby the presence of outliers in the distribution of TSS concentrations was observed in the outlet stream, while for FOG concentrations, outliers were observed in the inlet stream. As in the previous section, these outliers were replaced by the median of the individual quality parameter distribution to produce distributions without outliers, as depicted in Figure 13b. The replacement of these outliers resulted in a reliable distribution depicted in Figure 14.
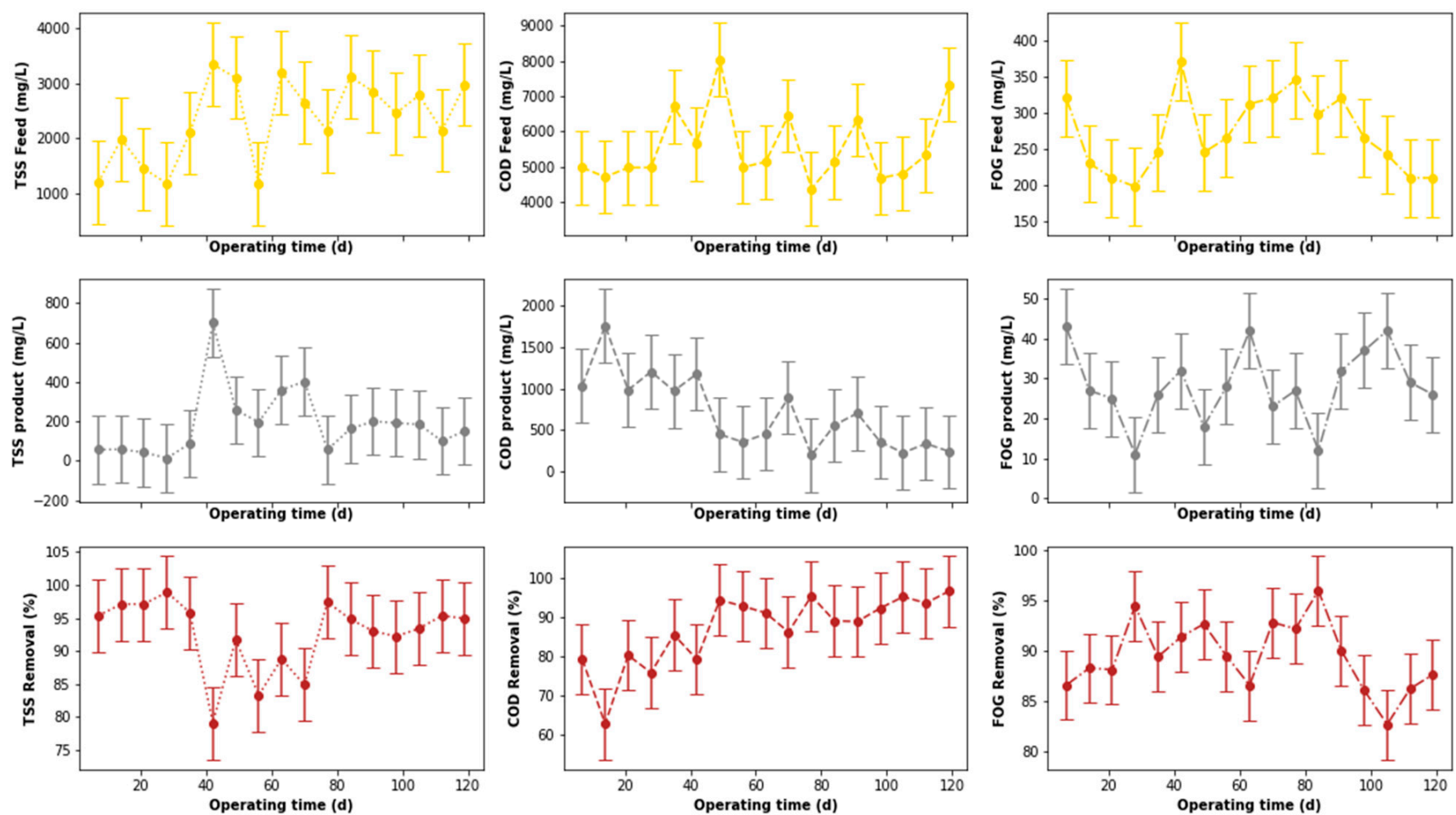

Figure 12. Performance of PSW DEGBR before outliers' detection and replacement.

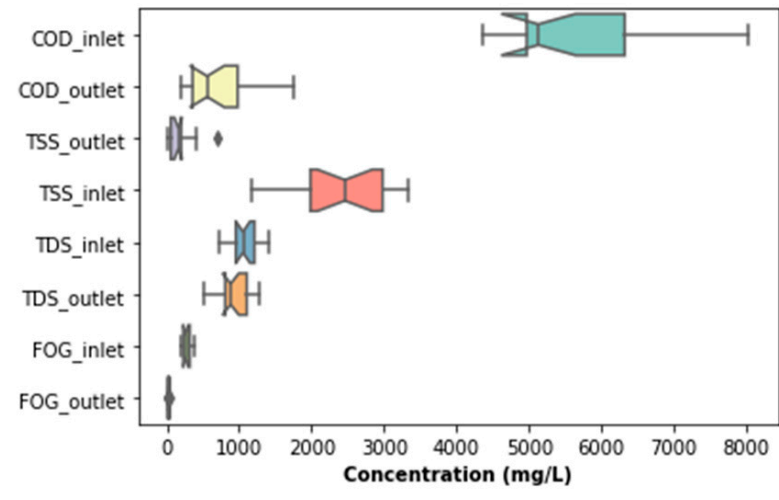

(a)

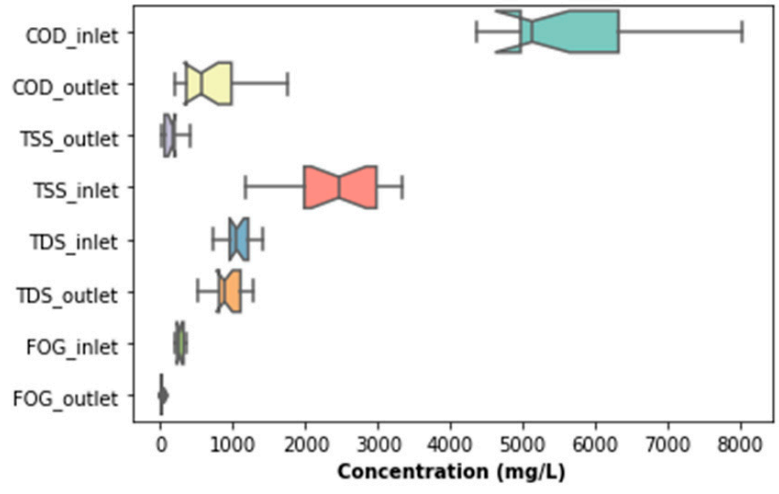

(b)

Figure 13. Boxplots of the DEGBR highlighted features before and after outliers' replacement: (a) Boxplots before outliers' replacement; (b) boxplots after outliers' replacement. 

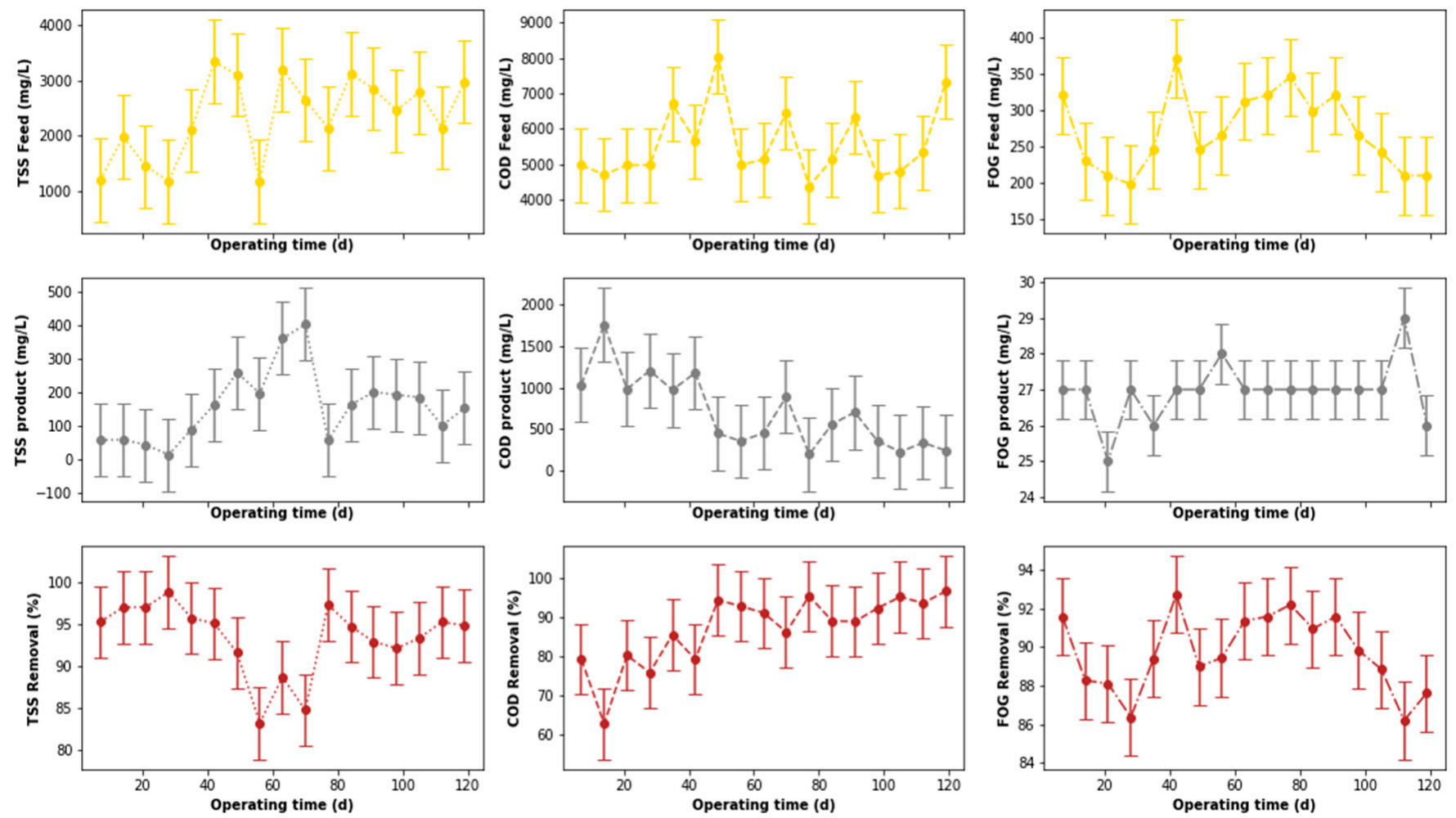

Figure 14. Performance of PSW DEGBR after outliers' detection and replacement.

A comparison of the removal efficiencies varied throughout the study (see Figure 14) with indications that there was a slight change in the removal efficiencies between days 40 to 75 for the TSS removal. The alteration of the performance of the DEGBR for the removal of TSS was reduced during days 56 to 70. An improvement in the performance of the DEGBR after the outlier replacement was also noticed with the removal of FOG during days 14 to 28 , and 102 to 109 . At this stage it was not clear as to the reasons why the observed changes were observed, which is an indication that further analyses are required.

The performance of the DEGBR was further assessed for relatedness, as shown in Figures 15-17, which showed the response of the DEGBR in terms of the removal of the FOG, COD, and TSS, respectively, when a variation of the OLR was implemented in the experiment. A comparison of these graphs shows a better response of the DEGBR for the removal of COD, despite the various fluctuations of the OLR varying from 18 to $\sim 45$ gCOD/L.d. Despite a good consistency in the evolution of the COD removal efficiencies, the DEGBR performance was higher at the beginning of the process for both the TSS and FOG removal efficiencies, as displayed in Figures 16 and 17, with ranges varying between $\sim 84$ and $\sim 98 \%$ for the TSS removal, and $\sim 85 \%$ and $\sim 93 \%$ for the FOG removal, which is an indication that the AD bed acted as a bio-filter, perhaps with some hydrolysis capacity. 


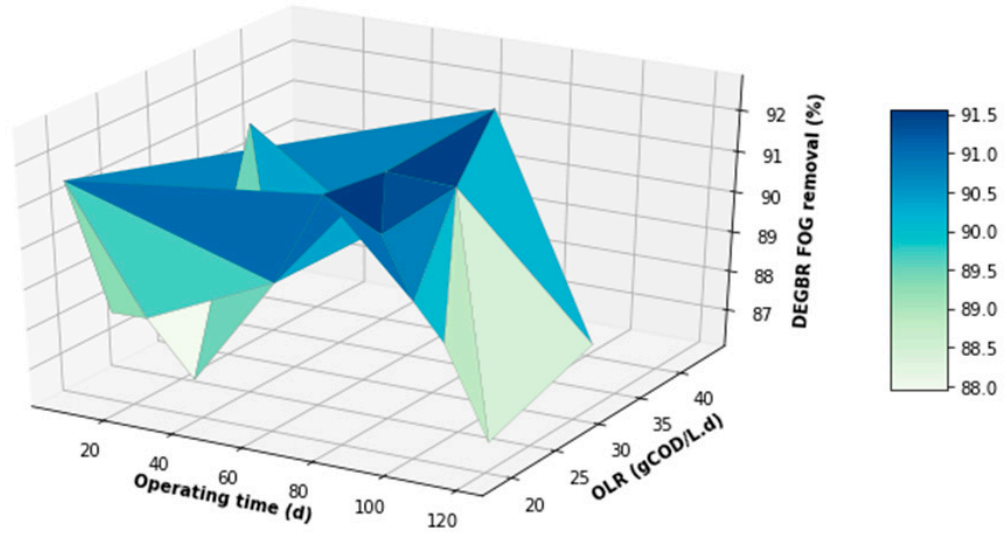

Figure 15. DEGBR FOG removal with respect to the operating time and the OLR.

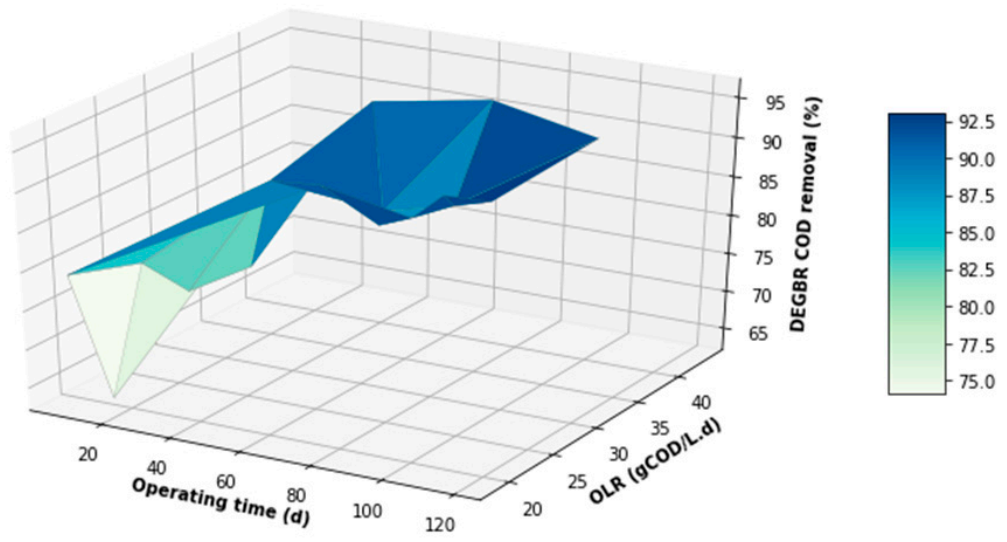

Figure 16. DEGBR COD removal with respect to the operating time and the OLR.

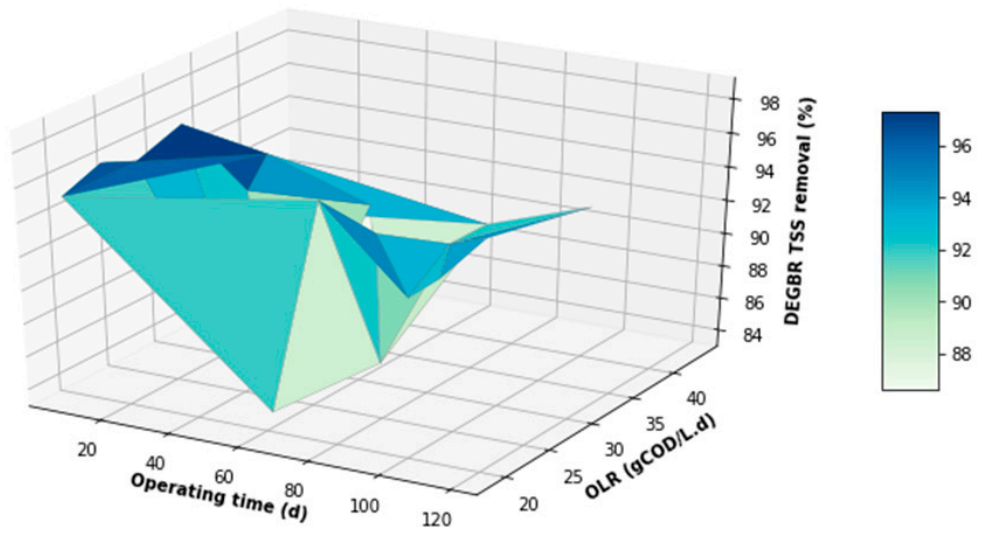

Figure 17. DEGBR TSS removal with respect to the operating time and the OLR.

A feasible correlation between these removal efficiencies from the DEGBR treatment was evaluated using a correlation display, as illustrated in Figure 18. The latter shows a minimal correlation between the COD, FOG, and TSS removal efficiencies, as demonstrated by the low Pearson's correlation coefficients. A further evaluation of the quality of the distribution of each of these removal efficiencies as well as the mean of each distribution is depicted in Figure 19. From the latter, it can be seen that the DEGBR performed the best for the removal of TSS with a mean removal percentage value of $93 \%$, followed by the FOG mean removal percentage with an averaged value of $\sim 90 \%$, and the COD mean removal percentage with a value of $\sim 87 \%$. The distribution of the removal efficiency values was 
more skewed and tailed for the TSS and the COD removal, and less skewed and tailed for FOG removal; overall, the DEGBR displayed a good performance for the removal of these contaminants, which were further removed in the post-treatment stage using an MBR.
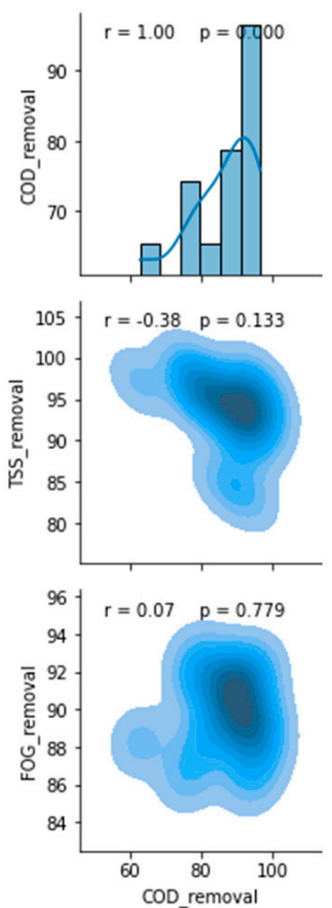
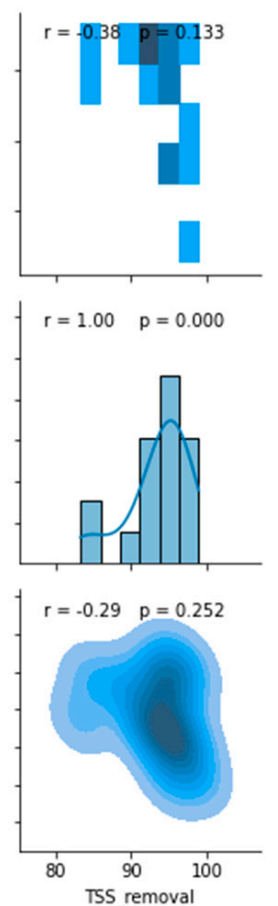
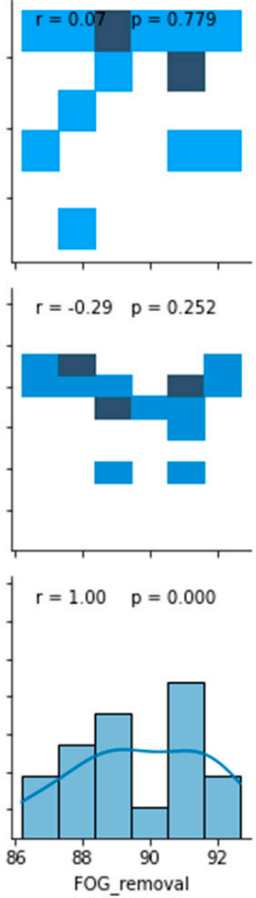

Figure 18. Correlation matrix between removal efficiencies of the DEGBR.
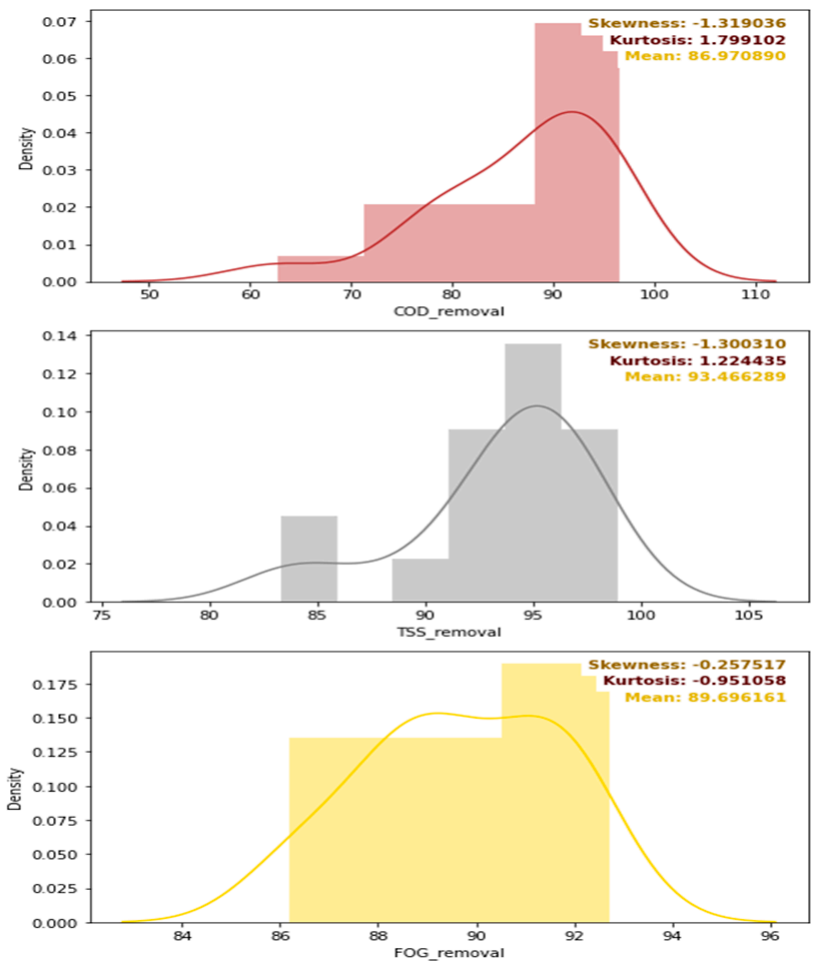

Figure 19. Density distribution, skewness, kurtosis, and mean values of the removal efficiencies of the DEGBR. 
With reference to the reactor limitations and rationale mentioned in Table 2, the observed DEGBR performance displayed an improved performance with no signs of clogging nor need for backwashing [13,14,22].

\subsubsection{DEGBR-MBR Post-Treatment}

A post-treatment stage consisting of an MBR was coupled to the DEGBR to further decrease the concentration of contaminants from the PSW. Figure 20 provides the variation of the concentration of the TSS, COD, and FOG both at the inlet and outlet of the MBR throughout the study. The boxplots of the assessed parameters reveal that there were no outliers in each distribution investigated, which indicated the consistency in the performance of the MBR unit. The removal efficiency values of the TSS remained consistently high after day 42 of operation, while an inconsistent variation was noticed for the COD and the FOG, albeit with minute variations. Similarly, to the DEGBR, a minimal correlation was found between these removal efficiencies, as depicted in Figure 21.

Figure 22 provides the density distribution, the skewness, the kurtosis, and the removal efficiency values from the MBR unit. A comparison between Figures 19 and 22 shows that the DEGBR performed better than the MBR unit in terms of removal efficiency of the TSS and FOG. The MBR unit performed slightly better than the DEGBR for the mean removal efficiency of the COD, indicating its suitability as a polishing stage, i.e., the MBR unit performance significantly improved the quality of the treated PSW and contributed to the improved overall performance of the system composed of the pre-treatment stage, the DEGBR, and the MBR units. As shown in Figure 23, it can be observed that the performance of the overall process was $>98 \%$ throughout the study.
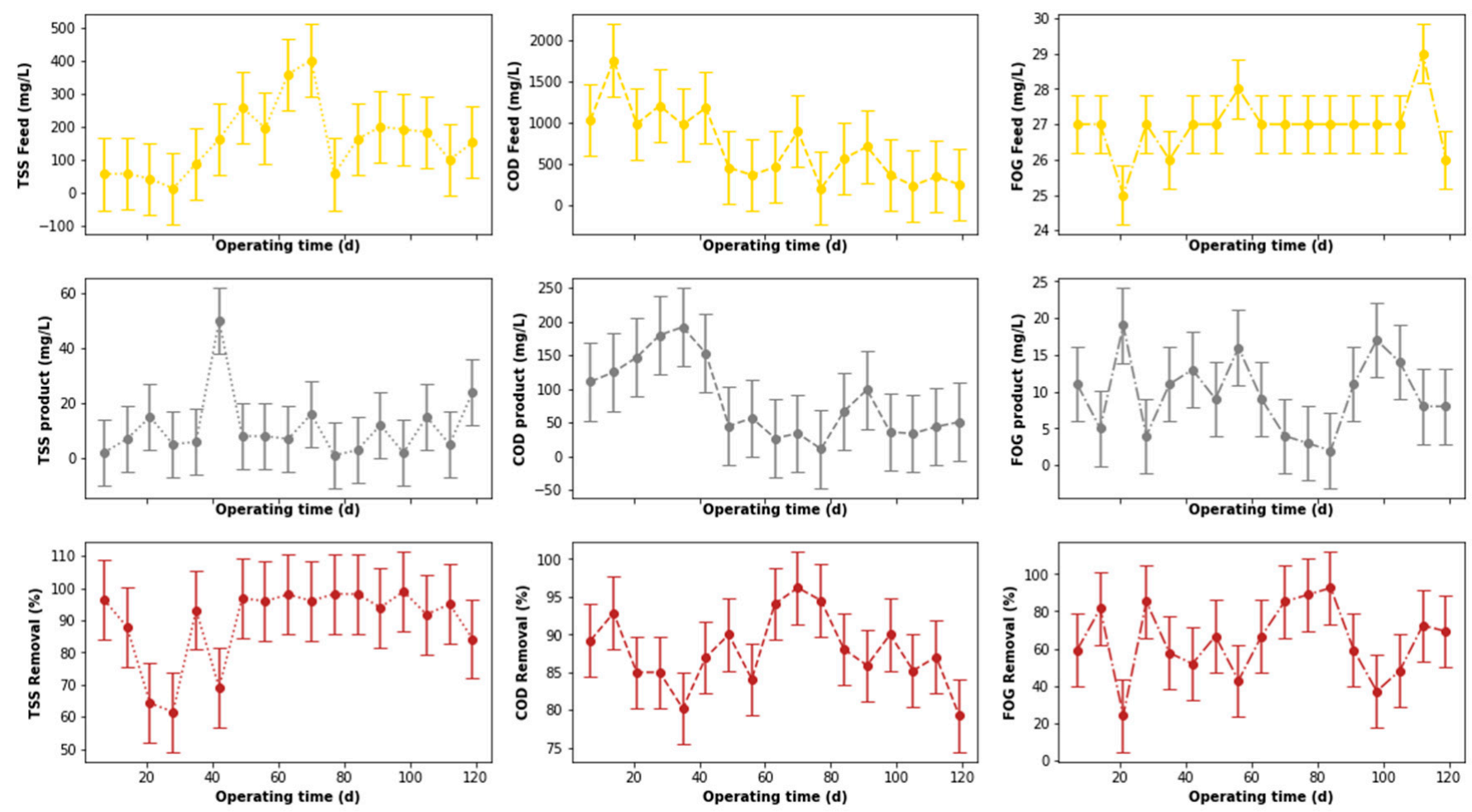

Figure 20. Performance of the MBR after the DEGBR treatment. 

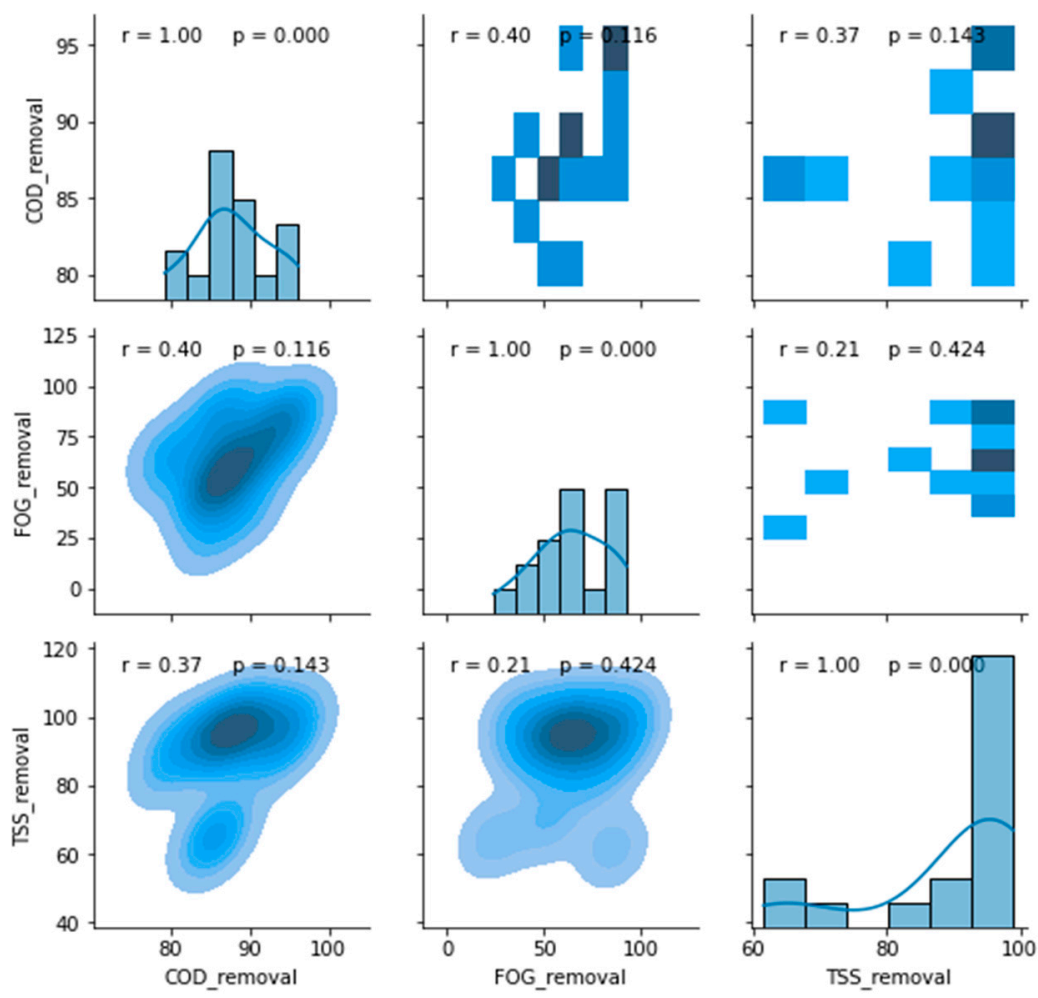

Figure 21. Correlation matrix between removal efficiencies of the MBR after DEGBR treatment.
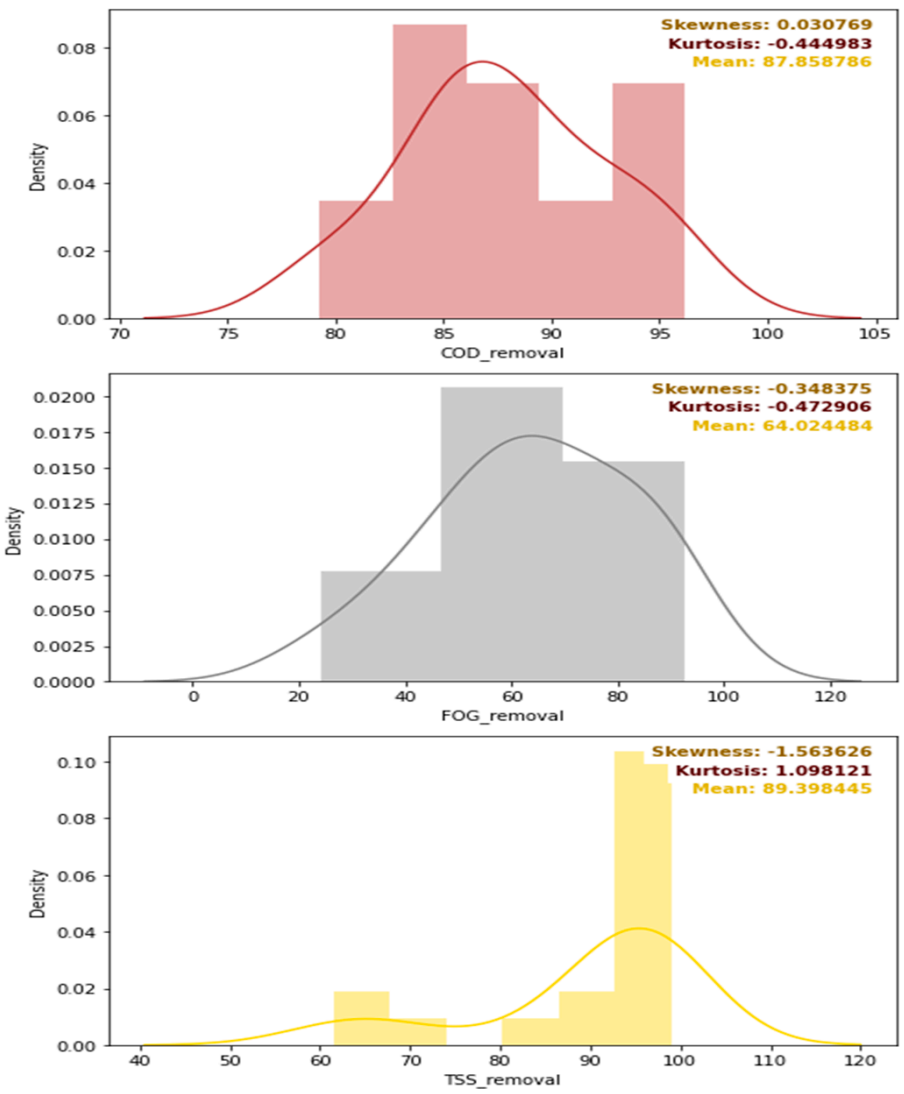

Figure 22. Density distribution, skewness, kurtosis, and mean values of the removal efficiencies of the MBR after DEGBR treatment. 

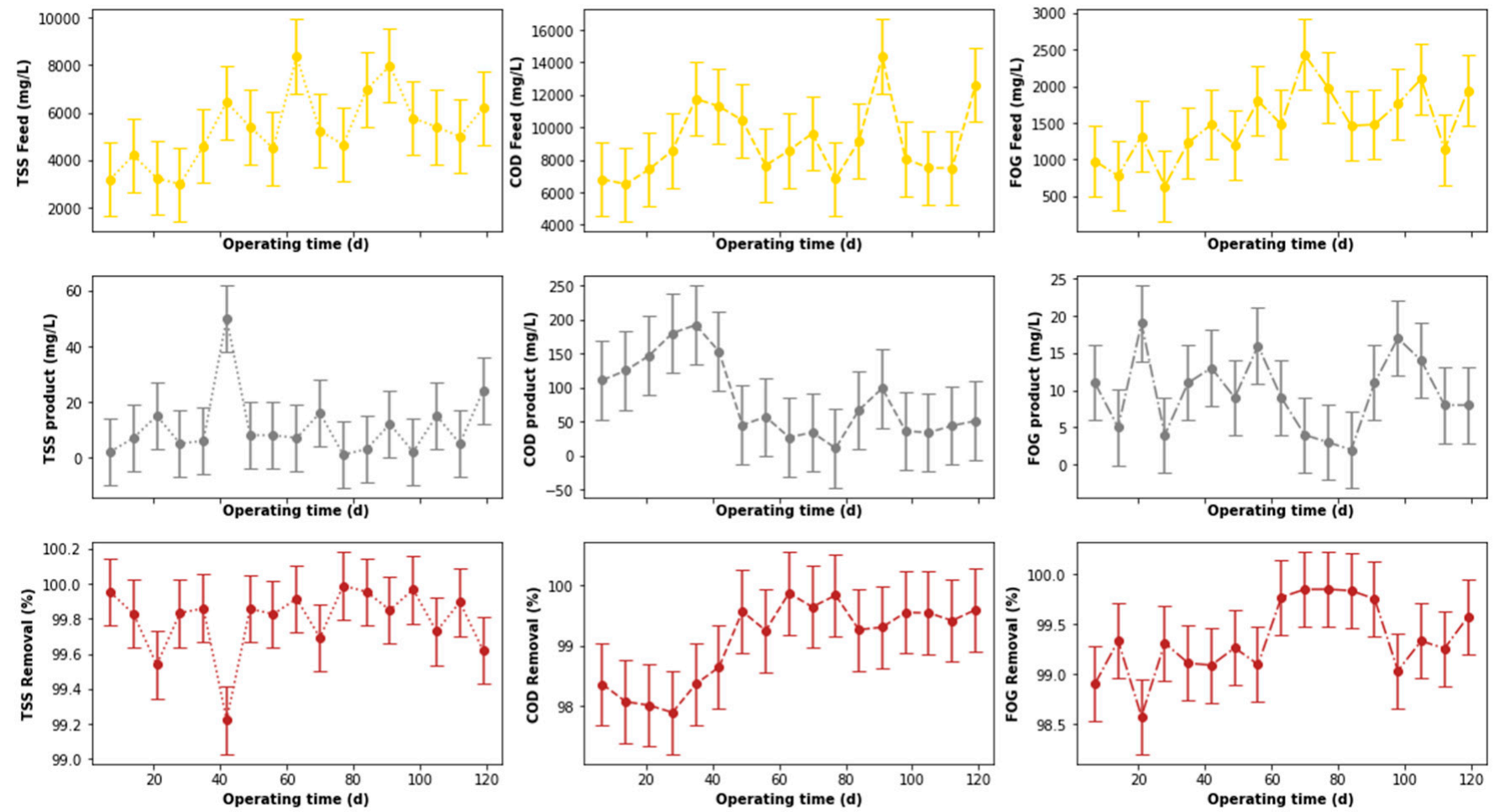

Figure 23. Overall performance of the combination of the pre-treatment stage, the DEGBR, and the MBR.

\subsubsection{Overall Performance of Pre-Treatment-DEGBR-MBR System}

The overall performance of the integrated system combining a pre-treatment stage, the DEGBR, and the MBR is provided in Figure 23. This indicated a commendable performance of the system, with overall removal efficiency values of the FOG, COD, and TSS being $>98 \%$ throughout the study. Although, Figure 24 indicated a minimal correlation between the removal efficiency of the FOG, COD, and TSS in the overall system, highlighting the suitability of such a system for the treatment of PSW or similar type of wastewater. The integration of different stages in the process addresses the shortcomings that one stage may have, and this can lead to overall potable water savings and perhaps the reuse of the treated water for other purposes such as irrigation - which, at this stage, still needs to be evaluated.

Figure 25 provides the density distribution, the skewness, the kurtosis, and the removal efficiency values of the combination of the pre-treatment stage, the DEGBR, and the MBR. A comparison between Figures 19 and 22, Figure 25 shows that the increased removal efficiency of the combined pre-treatment-DEGBR-MBR approach which resulted in FOG, TSS and COD removal higher than $99 \%$.

Despite these results signifying a positive membrane unit functionality, circumventing the typical membrane challenges such as clogging and membrane fouling, there was evident foam build-up during aeration. Furthermore, biofilm formed at the bottom of the membrane unit when an EGSB was used (shown in Figure 26a). The MBR operation was stopped after operating for 5 weeks due to signs of extracellular polymeric substances (EPS) build-up, as shown in Figure 26b. Thus, validating a re-evaluation of the sludge retention times (SRT) and aeration rate cited in some MBR operations [26] with excessive aeration being required, while extremely low SRTs were required due to the increased EPS in the MBR downstream. This presented a challenge that needs to be addressed in subsequent studies. 

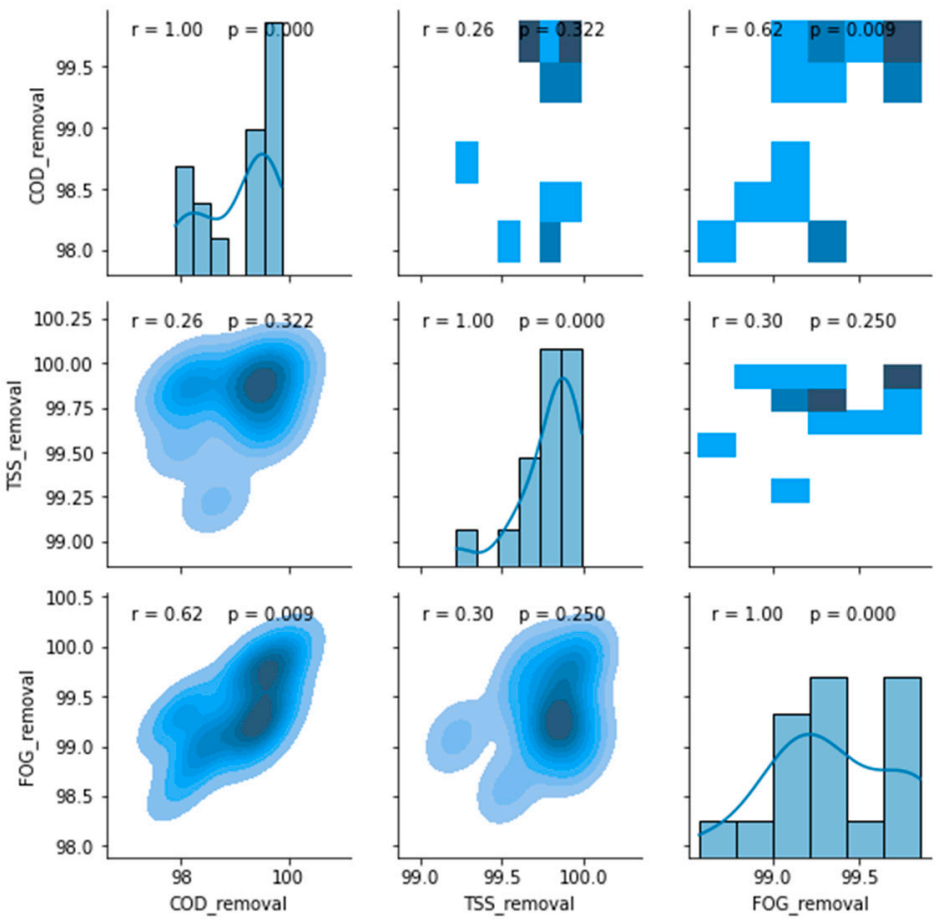

Figure 24. Correlation matrix between removal efficiencies of the combination of the pre-treatment stage, the DEGBR, and the MBR.
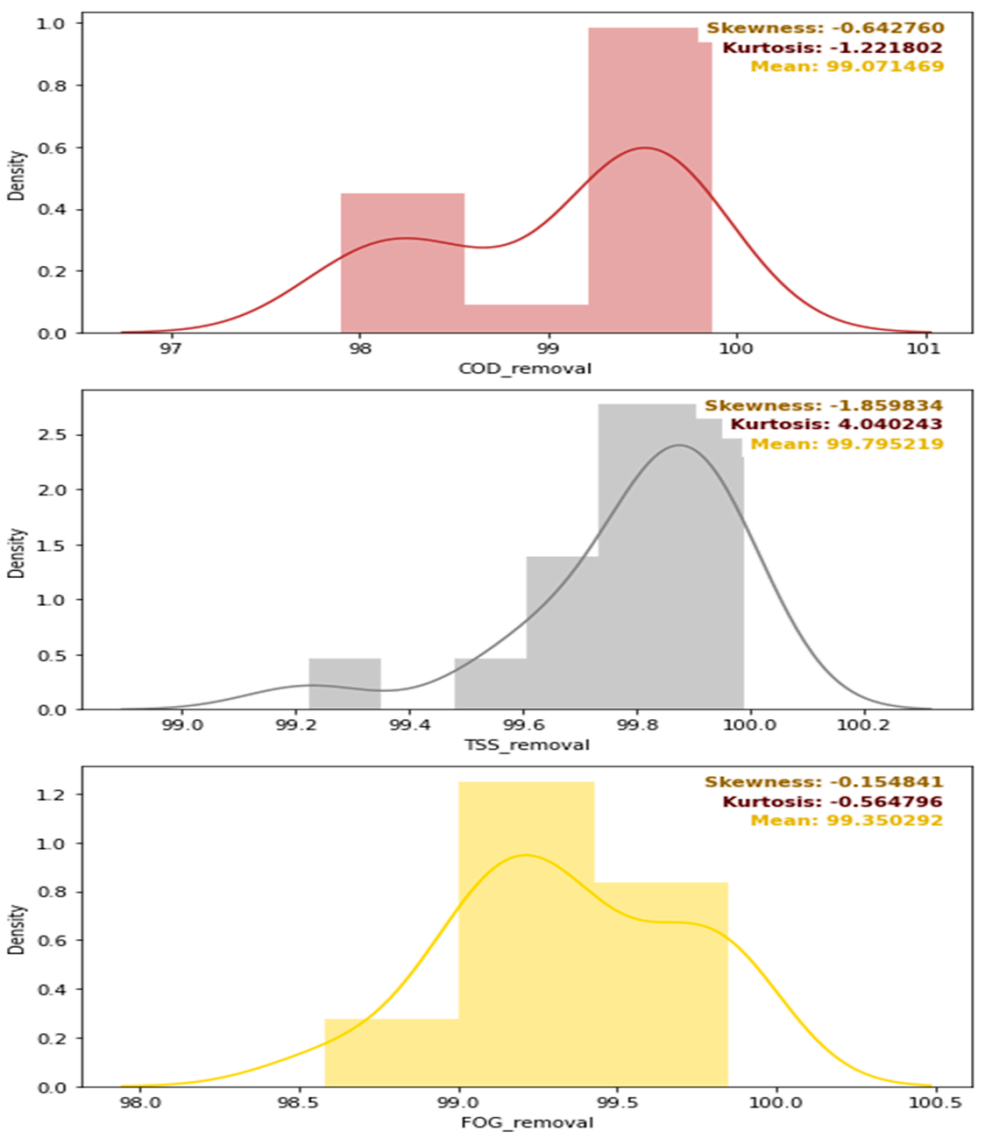

Figure 25. Density distribution, skewness, kurtosis, and mean values of the removal efficiencies of the combination of the pre-treatment stage, the DEGBR, and the MBR. 


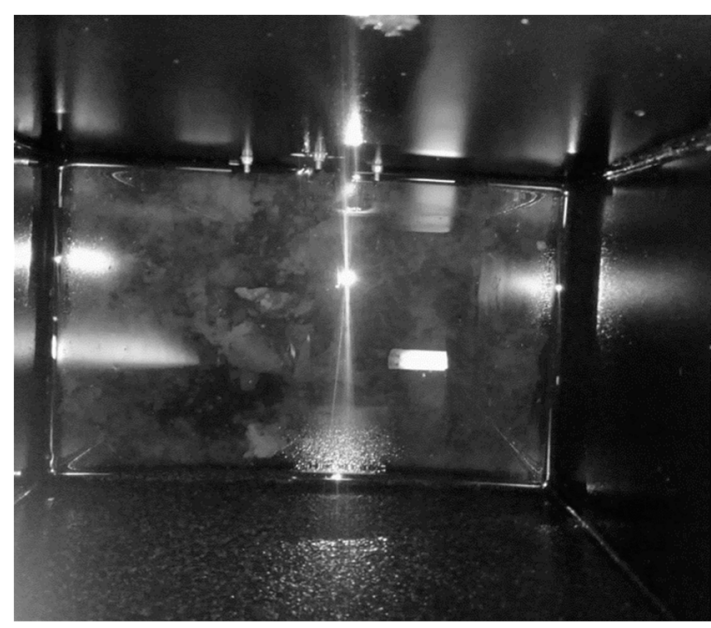

(a)

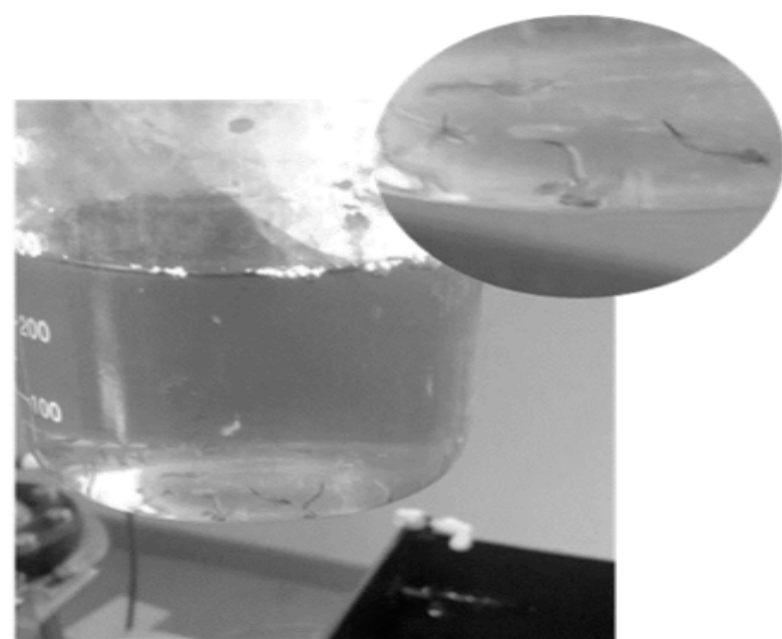

(b)

Figure 26. (a) Biofilm at the bottom of the membrane; (b) Membrane sample during treatment.

\section{Conclusions}

The use of a commercially viable bacterial suspension has provided a significant impactful FOG remediation strategy for PSW treatment, especially with regard to FOG removal. The study investigated the effectiveness of the implemented bio-physico-pretreatment process, which has been proven to show a significant FOG concentration removal of $80 \%$, which, in turn, aided the AD reactor performance.

Furthermore, this study also evaluated the Pre-treatment-DEGBR-MBR unit set-up in the form of a laboratory-plant for PSW treatment. The DEGBR achieved effective PSW containment removal at an HRT of $5.4 \mathrm{~h}$ and OLR range of $\sim 18-\sim 44 \mathrm{~g} \mathrm{COD} / \mathrm{L} \cdot \mathrm{h}$. Moreover, the addition of the tertiary MBR stage offered a further treatment opportunity, which was achieved by a removal amount of $99 \%$ for COD, TSS, and FOG. The resultant effluent exceeded the set standard for effluent discharge. The system can be recommended as an effective solution for voluminous bird slaughtering industries.

Author Contributions: Conceptualisation, M.B., P.A.D., E.K., C.M. and S.K.O.N.; methodology, P.A.D. and C.M.; software, M.N.; validation, M.B. and M.N.; formal data collection, P.A.D. and C.M.; formal data reanalysis and validation: M.N. and S.K.O.N.; investigation, P.A.D. and C.M.; resources, M.B.; data curation, P.A.D. and C.M.; writing-original draft preparation, P.A.D. and C.M.; writing-review and editing, S.K.O.N. and M.B.; visualisation, M.N., E.K. and P.A.D.; supervision, M.B. and S.K.O.N.; project administration, S.K.O.N.; funding acquisition, S.K.O.N. and M.B. All authors have read and agreed to the published version of the manuscript.

Funding: Cape Peninsula University of Technology cost code RK45 and the National Research Foundation Thuthuka Funding, R017.

Institutional Review Board Statement: Not applicable.

Informed Consent Statement: Not applicable.

Data Availability Statement: Not applicable.

Acknowledgments: The authors wish to acknowledge the South African Breweries (SAB) for the AD granules, Malutsa (Pty) Ltd. for the construction of the Laboratory-scale plant, and Mavu Biotechnologies (Pty) Ltd. for donating the Eco-flush ${ }^{\mathrm{TM}}$.

Conflicts of Interest: The authors declare no conflict of interest. The funders had no role in the design of the study; in the collection, analyses, or interpretation of data; in the writing of the manuscript, or in the decision to publish the results. 


\section{References}

1. $\quad$ Basitere, M.; Williams, Y.; Sheldon, M.S.; Ntwampe, S.K.O.; de Jager, D. Performance of an expanded granular sludge bed (EGSB) reactor coupled with anoxic and aerobic bioreactors for treating poultry slaughterhouse wastewater. Water Pract. Technol. 2016, 11, 86-92. [CrossRef]

2. Aljuboori, A.H.R.; Idris, A.; Abdullah, N.; Mohamad, R. Production and characterization of a bioflocculant produced by Aspergillus flavus. Bioresour. Technol. 2013, 127, 489-493. [CrossRef] [PubMed]

3. Njoya, M.; Basitere, M.; Ntwampe, S.K.O. Analysis of the characteristics of poultry slaughterhouse wastewater (PSW) and its treatability. Water Pract. Technol. 2019, 14, 959-970. [CrossRef]

4. Bustillo-Lecompte, C.; Mehrvar, M. Slaughterhouse Wastewater: Treatment, Management and Resource Recovery. Phys. Chem. Wastewater Treat. Resour. Recovery 2017, 153-174. [CrossRef]

5. Aziz, A.; Basheer, F.; Sengar, A.; Ullah, S.; Haq, I. Science of the Total Environment Biological wastewater treatment (anaerobicaerobic) technologies for safe discharge of treated slaughterhouse and meat processing wastewater. Sci. Total. Environ. 2019, 686, 681-708. [CrossRef] [PubMed]

6. Lippi, M.; Ley, M.B.R.G.; Mendez, G.P.; Junior, R.A.F.C. State of Art of Landfill Leachate Treatment: Literature Review and Critical Evaluation. Ciência e Nat. 2018, 40, 78. [CrossRef]

7. Koli, S.K.; Hussain, A. Status of Electronic Waste Management in India. Adv. Treat. Tech. Ind. Wastewater. 2018, 238-250. [CrossRef]

8. Njoya, M.; Basitere, M.; Ntwampe, S.K.O. Treatment of poultry slaughterhouse wastewater using a down-flow expanded granular bed reactor. Water Pract. Technol. 2019, 14, 549-559. [CrossRef]

9. Wett, B.; Buchauer, K. Comparison of Aerobic and Anaerobic Technologies for Domestic Wastewater Treatment Based on Case Studies in Latin America. In Proceedings of the Seminario Problemas y Soluciones Ambientales, Aguas Residuales y Residuos Solidos, Medellin-Bogota-Quito, 2003; pp. 1-14. Available online: http://www.araconsult.at/download/literature/bogota_wett_ lg.pdf (accessed on 15 May 2021).

10. Bustillo-Lecompte, C.F.; Mehrvar, M. Treatment of actual slaughterhouse wastewater by combined anaerobic-aerobic processes for biogas generation and removal of organics and nutrients: An optimization study towards a cleaner production in the meat processing industry. J. Clean. Prod. 2017, 141, 278-289. [CrossRef]

11. Sheldon, M.S.; Zeelie, P.J.; Edwards, W. Treatment of paper mill effluent using an anaerobic/aerobic hybrid side-stream Membrane Bioreactor. Water Sci. Technol. 2012, 65, 1265-1272. [CrossRef]

12. Damasceno, F.R.C.; Cavalcanti-Oliveira, E.D.; Kookos, I.K.; Koutinas, A.A.; Cammarota, M.C.; Freire, D.M.G. Treatment of wastewater with high fat content employing an enzyme pool and biosurfactant: Technical and economic feasibility. Braz. J. Chem. Eng. 2018, 35, 531-542. [CrossRef]

13. Polizelli, P.P.; Facchini, F.D.A.; Bonilla-Rodriguez, G.O. Stability of a lipase extracted from seeds of pachira aquatica in commercial detergents and application tests in poultry wastewater pretreatment and fat particle hydrolysis. Enzym. Res. 2013. [CrossRef]

14. Hernández-Fydrych, V.C.; Benítez-Olivares, G.; Meraz-Rodríguez, M.A.; Salazar-Peláez, M.L.; Fajardo-Ortiz, M.C. Methane production kinetics of pretreated slaughterhouse wastewater. Biomass Bioenergy 2019, 130, 105385. [CrossRef]

15. de Nardi, I.R.; Fuzi, T.P.; del Nery, V. Performance evaluation and operating strategies of dissolved-air flotation system treating poultry slaughterhouse wastewater. Resour. Conserv. Recycl. 2008, 52, 533-544. [CrossRef]

16. Dors, G.; Mendes, A.A.; Pereira, E.B.; de Castro, H.F.; Furigo, A. Simultaneous enzymatic hydrolysis and anaerobic biodegradation of lipid-rich wastewater from poultry industry. Appl. Water Sci. 2013, 3, 343-349. [CrossRef]

17. Liew, Y.X.; Chan, Y.J.; Manickam, S.; Chong, M.F.; Chong, S.; Tiong, T.J.; Lim, J.W.; Pan, G.-T. Enzymatic pretreatment to enhance anaerobic bioconversion of high strength wastewater to biogas: A review. Sci. Total. Environ. 2020, 713, 136373. [CrossRef] [PubMed]

18. Gogate, P.R.; Thanekar, P.D.; Oke, A.P. Strategies to improve biological oxidation of real wastewater using cavitation based pre-treatment approaches. Ultrason. Sonochemistry 2020, 64, 105016. [CrossRef] [PubMed]

19. Wachinski, A.M. Membrane Processes for Water Reuse; Mc Graw Hill: New York, NY, USA, 2013; pp. 81-114. ISBN 10:0071748954.

20. Basitere, M.; Rinquest, Z.; Njoya, M.; Sheldon, M.S.; Ntwampe, S.K.O. Treatment of poultry slaughterhouse wastewater using a static granular bed reactor (SGBR) coupled with ultrafiltration (UF) membrane system. Water Sci. Technol. 2017, 76, 106-114. [CrossRef] [PubMed]

21. Meyo, H.B.; Njoya, M.; Basitere, M.; Ntwampe, S.K.O.; Kaskote, E. Treatment of Poultry Slaughterhouse Wastewater (PSW) Using a Pretreatment Stage, an Expanded Granular Sludge Bed Reactor (EGSB), and a Membrane Bioreactor (MBR). Membranes 2021, 11, 345. [CrossRef] [PubMed]

22. Dlamini, D.N.; Basitere, M.; Njoya, M.; Karabo, S.; Ntwampe, O.; Kaskote, E. Applied Sciences Performance Evaluation of a Biological Pre-Treatment Coupled with the Down-Flow Expanded Granular Bed Reactor (DEGBR) for Treatment of Poultry Slaughterhouse Wastewater. Appl. Sci. 2021, 11, 6536. [CrossRef]

23. Rinquest, Z.; Basitere, M.; Ntwampe, S.K.O.; Njoya, M. Poultry slaughterhouse wastewater treatment using a static granular bed reactor coupled with single stage nitrification-denitrification and ultrafiltration systems. J. Water Process. Eng. 2019, $29,100778$. [CrossRef]

24. Debik, E.; Coskun, T. Use of the Static Granular Bed Reactor (SGBR) with anaerobic sludge to treat poultry slaughterhouse wastewater and kinetic modeling. Bioresour. Technol. 2009, 100, 2777-2782. [CrossRef] 
25. Ergofito. Poultry Farming, in Cape Town. 2019, p. 4. Available online: https:/ /www.ergofito.co.za/application/Grease-FatsOverview (accessed on 15 May 2021).

26. Water Environment Federation. Membrane Bioreactors: WEF Manual of Practice No. 36 (McGraw-Hilll Education: New York, Chicago, San Francisco, Lisbon, London, Madrid, Mexico City, Milan, New Delhi, San Juan, Seoul, Singapore, Sydney, Toronto, 2012). Available online: https://www.accessengineeringlibrary.com/content/book/9780071753661 (accessed on 15 May 2021). 